OPEN ACCESS

Edited by:

Albert Rizvanov,

Kazan Federal University, Russia

Reviewed by:

Medardo Hernández,

Complutense University of Madrid,

Spain

Vincent C. Lombardi

Nevada Center for Biomedical

Research, University of Nevada,

Reno, United States

${ }^{*}$ Correspondence:

Fabiola M. Ribeiro

fmribeiro@icb.ufmg.br;

fmribeiro2013@gmail.com

${ }^{t}$ These authors have contributed equally to this work.

Specialty section:

This article was submitted to Experimental Pharmacology and Drug

Discovery,

a section of the journal

Frontiers in Pharmacology

Received: 01 December 2017

Accepted: 09 February 2018

Published: 23 February 2018

Citation:

de Souza JM, Goncalves BDC, Gomez MV, Vieira LB and Ribeiro FM (2018) Animal Toxins as Therapeutic

Tools to Treat Neurodegenerative Diseases. Front. Pharmacol. 9:145. doi: 10.3389/fphar.2018.00145

\section{Animal Toxins as Therapeutic Tools to Treat Neurodegenerative Diseases}

\author{
Jessica M. de Souza ${ }^{1 t}$, Bruno D. C. Goncalves ${ }^{2 t}$, Marcus V. Gomez ${ }^{3}$, Luciene B. Vieira ${ }^{2}$ \\ and Fabiola M. Ribeiro ${ }^{1 *}$
}

' Department of Biochemistry and Immunology, Institute of Biological Sciences, Universidade Federal de Minas Gerais, Belo Horizonte, Brazil, ${ }^{2}$ Department of Pharmacology, Institute of Biological Sciences, Universidade Federal de Minas Gerais, Belo Horizonte, Brazil, ${ }^{3}$ Department of Neurotransmitters, Instituto de Ensino e Pesquisa Santa Casa, Belo Horizonte, Brazil

Neurodegenerative diseases affect millions of individuals worldwide. So far, no diseasemodifying drug is available to treat patients, making the search for effective drugs an urgent need. Neurodegeneration is triggered by the activation of several cellular processes, including oxidative stress, mitochondrial impairment, neuroinflammation, aging, aggregate formation, glutamatergic excitotoxicity, and apoptosis. Therefore, many research groups aim to identify drugs that may inhibit one or more of these events leading to neuronal cell death. Venoms are fruitful natural sources of new molecules, which have been relentlessly enhanced by evolution through natural selection. Several studies indicate that venom components can exhibit selectivity and affinity for a wide variety of targets in mammalian systems. For instance, an expressive number of natural peptides identified in venoms from animals, such as snakes, scorpions, bees, and spiders, were shown to lessen inflammation, regulate glutamate release, modify neurotransmitter levels, block ion channel activation, decrease the number of protein aggregates, and increase the levels of neuroprotective factors. Thus, these venom components hold potential as therapeutic tools to slow or even halt neurodegeneration. However, there are many technological issues to overcome, as venom peptides are hard to obtain and characterize and the amount obtained from natural sources is insufficient to perform all the necessary experiments and tests. Fortunately, technological improvements regarding heterologous protein expression, as well as peptide chemical synthesis will help to provide enough quantities and allow chemical and pharmacological enhancements of these natural occurring compounds. Thus, the main focus of this review is to highlight the most promising studies evaluating animal toxins as therapeutic tools to treat a wide variety of neurodegenerative conditions, including Alzheimer's disease, Parkinson's disease, brain ischemia, glaucoma, amyotrophic lateral sclerosis, and multiple sclerosis.

Keywords: neurodegenerative disease, neuronal death, neuroinflammation, excitotoxicity, animal venom, toxins

\section{ANIMAL TOXINS}

Living organisms have to adapt to the different environments and face competition from other creatures, as all species are challenged by natural selection (Darwin, 1859). In the course of evolution, species equipped with specific traits that conferred some kind of benefit regarding their basic needs have advantage over others. Venoms and toxins are therefore products of natural 
selection. Accordingly, toxins and venoms have evolved independently and can be found in several different taxa, including plants, microbes, cnidarians, mollusks, arthropods, and reptiles. These venoms contain different molecules, including inorganic ions, proteins, nucleotides and enzymes, and can trigger a wide variety of effects, such as hemorrhage, necrosis or neurotoxicity (Fry et al., 2009). Organisms, in most cases, evolved their venoms as part of predatory and defensive strategies, on a continuous long term coevolutionary process. For instance, resistance to snake venom by some of the prey or predators of snakes arouse several times in the course of evolution (Biardi and Coss, 2011; Jansa and Voss, 2011). As analysis of different species reveals a great molecular diversity regarding physiological elements such as enzymes, channels, receptors and other potential targets for toxins, it is easy to understand that evolution can be held responsible for such diversified composition of venoms targeting these elements. Toxins present in these venoms are very specific and potent (Zhang, 2015). Moreover, their components effects are often synergic, an important adaptation to reduce the amount of venom dispensed, considering the elevated metabolic cost of venom production (Nisani et al., 2007, 2012).

Humans have evolved together with venomous animals, and as such, many animal toxins have coevolved with our species. Moreover, animal envenomation has been in the past and still is a worldwide issue and a big cause of mortality and morbidity (Kasturiratne et al., 2008; Balhara and Stolbach, 2014). In that way, research on animal venoms and toxins was initially focused on neutralizing venoms effects and treating animal envenomation. However, in 1781, the Italian naturalist Felice Fontana started investigations on the effects of snake venom against blood coagulation. Later, by the 1890s, the first antivenom therapy was developed by the scientists Albert Calmette, Césaire Auguste Phisalix, and Gabriel Bertrand (Calmette, 1894; Phisalix and Bertrand, 1894). However, as the knowledge about the physiology of venoms and toxins expanded, from foe to friend, these substances became valuable resources for scientific research. For many years now natural toxins have been used as research tools. Experiments using a pufferfish toxin were

Abbreviations: $\mathrm{A} \beta$, amyloid beta; $\mathrm{AChE}$, acetyl cholinesterase; $\mathrm{AD}$, Alzheimer's Disease; ALS, amyotrophic lateral sclerosis; AMPA, $\alpha$-amino-3-hydroxy-5-methyl4-isoxazolepropionic acid; APP, amyloid precursor protein; ASIC, acid-sensing ion channel; BBB, blood-brain-barrier; Bmk, Buthus martensii kirsch; BV, bee venom; BVPLA 2 , bee venom phospholipase A2; CNS, central nervous system; ECE-1, endothelin-converting-enzyme-1; FDA, Federal Drugs Administration; GFP, green fluosrescent protein; HD, Huntington's Disease; HWTX-I, huwentoxinI; i.c.v., intracerebroventricular; i.p., intraperitoneal; IFN $\beta$, interferon- $\beta$; IL-1, interleukin-1; iNOS, inducible nitric oxide synthase; LPS, lipopolysaccharide; MAC-1, macrophage antigen complex-1; MAO-B, monoamine oxidase-B; MCA, middle cervical artery; MDA, malondialdehyde; mGluR, metabotropic glutamate receptor; MPP+, 1-methyl-4-phenylpyridinium; MPTP, 1-methyl-4phenyl-1,2,3,6-tetrahydropyridine; MS, multiple sclerosis; NEP, neprilysin; NFT, neurofibrillary tangles; NMDA, $N$-methyl-D-aspartate; ODLG, oxygen deprivation low glucose; PcTX, psalmotoxin-1; PD, Parkinson's Disease; PGE2, prostaglandin E2; PLA 2 , phospholipase A2; PON1, paraxonase-1; PS, presenelin; RGCs, retinal ganglion cells; ROS, reactive oxygen species; RVV-V, Russian viper venom factor $\mathrm{V}$; SNpc, substancia nigra pars compacta; SOD, superoxide dismutase; SSM, Scolopendra subspinipes mutilans; SVHRP, scorpion venom heat resistant peptide; $\mathrm{TNF} \alpha$, tumor necrosis factor $\alpha$; UPS, ubiquitin proteasome system; VSSC, voltage sensitive calcium channel; WT, wild type. determinant to establish the contribution of $\mathrm{Na}^{+}$and $\mathrm{K}^{+}$ channels to the action potential (Narahashi et al., 1969). The isolation of toxins from snake venom, such as $\alpha$-bungarotoxin and cobratoxin, allowed the successful purification of nicotinic receptors and its subsequent cloning (Changeux et al., 1970). The $\omega$-conotoxin extracted from Conus snails, a fish-eating marine snail, was also very important for $\mathrm{N}$-type $\mathrm{Ca}^{2+}$ channel research and subgroups of other toxins generated by biotechnological engineering permitted studies of several subtypes of voltagedependent $\mathrm{Ca}^{2+}$ channels (VDCCs) (Olivera et al., 1987; McEnery et al., 1991).

Notably, venoms from several species are under investigation for the treatment of a variety of pathologies, including cardiovascular disorders, pain, cancer, and several neurodegenerative diseases (Brunner et al., 1980; Bowersox et al., 1996; da Silva et al., 2002; Castro et al., 2005; Ye et al., 2016b). The great diversity of the components contained in the venom of several animal species, as well as their high specificity to cell targets, contribute to making the pharmacological research of toxins an interesting field. Therefore, advances in the understanding of neurodegenerative disorders and the consequent emergence of novel drug targets increases the potential for animal toxins as lead candidates for drug development. This review will cover the current available literature regarding the use of natural toxins to develop therapeutic tools to treat neurodegenerative diseases.

\section{NEURODEGENERATION}

Neurodegeneration is the underlying cause of a wide variety of neurological pathologies, including Alzheimer's disease (AD), Parkinson's disease (PD), Huntington's disease (HD) and cerebral ischemia (Macdonald et al., 1993; Lang and Lozano, 1998; Goedert and Spillantini, 2006; Kalogeris et al., 2012). The pathological mechanisms underlying these diseases are characterized by loss of tissue structure and cell function in selected vulnerable neural systems, which may lead to gradual cognitive and motor deficits, as well as psychiatric disturbance (Yan et al., 2013). Despite tremendous scientific efforts, the complexity of cell death processes and the difficulty to determine disease etiology pose many obstacles to the full understanding of these diseases and to develop disease-modifying therapies.

Neurons may undergo cell death through a variety of mechanisms, including apoptosis, necrosis, and autophagic cell death (Kroemer et al., 2009). The concept of apoptosis was established in Kerr et al. (1972) and is characterized by preservation of cellular ATP levels and the induction of a metabolic pathway leading to cell shrinkage, development of apoptotic bodies and phagocytosis of these cell fragments (Kerr et al., 1972; Richter et al., 1996; Elmore, 2007). Notably, caspases are the central components of the apoptotic response (Thornberry and Lazebnik, 1998; Shi, 2002; Kroemer et al., 2009). Conversely, necrosis is an acute form of cell death. It is characterized by a severe decrease of ATP levels, dispersion of ion gradients, cell dilatation and, ultimately, cell lysis (Kanno et al., 2006; Kroemer et al., 2009). The capture of the cytoplasmic 
material for mass degradation within autophagosomes occurs in a process called autophagic cell death (Levine and Kroemer, 2008; Booth et al., 2014). However, despite being conceptually different, these cell death mechanisms coexist and share some common features. Moreover, the neuropathological outcome for the CNS insults in animal models of excitotoxicity, cerebral ischemia, target deprivation/axotomy, and in human neurological disorders is not likely to result from a single process or causal mechanism. Numerous cell death stimuli can activate more than one mechanism of cell death depending on the situation, such as the elemental 'well-being' of the cell and the severity and duration of the stress (Yan et al., 2013).

Among the pathological processes that trigger cell death, excitotoxicity is particularly relevant, playing a crucial role in several neurodegenerative diseases. Despite intense research into the mechanisms underlying excitotoxicity, the intracellular mechanisms responsible for this type of neuronal cell death are yet to be fully elucidated. Excessive neuronal activation by excitatory neurotransmitters, such as glutamate, is considered to be the primary cause of excitotoxic injury (Garthwaite and Garthwaite, 1986; Marcaida et al., 1995; Nicholls et al., 1999; Arundine and Tymianski, 2004; Quillinan et al., 2016). Glutamate is the major excitatory neurotransmitter in the CNS (Arundine and Tymianski, 2004; Guerriero et al., 2015). There are two types of glutamate receptors: ionotropic, including $N$-methyl-D-aspartate (NMDA), $\alpha$-amino-3-hydroxy-5-methyl4-isoxazolepropionic acid (AMPA), and kainate; and mGluRs (Nakanishi and Masu, 1994). Acute CNS insults, such as ischemia and traumatic brain injury, induce intense release of glutamate, triggering overstimulation of glutamate receptors, especially NMDA receptors, and leading to massive influx of ions, in particular Ca ${ }^{2+}$ (Raichle, 1983; Choi, 1994; Quillinan et al., 2016). Destruction of ionic equilibrium depolarizes plasma membrane potential and reduces intracellular $\mathrm{pH}$ (Pepe, 2000; Azarias et al., 2011; Surin et al., 2014). $\mathrm{Ca}^{2+}$ captured in the mitochondria leads to mitochondrial membrane potential depolarization and disturbance of mitochondrial function (Miyamoto et al., 2005; Wang and Qin, 2010). The excessive activation of ATP-dependent ion pumps leads to ATP depletion and energetic stress, in an effort to reinstate ionic homeostasis (Garland and Halestrap, 1997; Mukherjee et al., 2008). The mechanisms involved in the metabolic response of neurons to excitotoxicity are complex and play a fundamental role in the capacity of the neuron to adapt and reclaim from such an insult.

Neurons are significantly more susceptible to metabolic stress triggered by excitotoxic events. These events can lead to an increase in ROS (Vergun et al., 2003). Although ROS are important intracellular signaling molecules, at high concentrations they can be cytotoxic, leading to oxidative stress (Touyz et al., 2003; Griffiths, 2005). ROS are described as a set of highly reactive molecules derived from oxygen, which contain unpaired valence electrons (Patten et al., 2010; Bolisetty and Jaimes, 2013). Included in the concept of ROS are the free radicals (superoxide, ${ }^{\bullet} \mathrm{O}_{2}{ }^{-}$, and hydroxyl radical, ${ }^{\bullet} \mathrm{OH}$ ) and nonradicals (hydrogen peroxide, $\mathrm{H}_{2} \mathrm{O}_{2}$ ), which originate by both exogenous and endogenous sources (Wu and Yotnda, 2011; Sinha et al., 2013). The major sources of ROS production is the mitochondrial respiratory chain and, in healthy condition, the production of ROS is equitable by different antioxidant processes (Gandhi and Abramov, 2012; Dasuri et al., 2013). Oxidative stress results from a divergence between ROS production and antioxidant defenses, bringing about overaccumulation of ROS. Oxidative stress can, therefore, promote structural damage to DNA, cell membrane injury and alterations in protein structure and function due to protein oxidation (Gandhi and Abramov, 2012). It has been demonstrated that increased levels of ROS play an important role in the pathogenesis of neurodegenerative diseases (Ray et al., 2012; Dasuri et al., 2013). For instance, increased indices of ROS have been found in the postmortem brain tissues from individuals with neurodegenerative disorders, including PD (Giasson et al., 2000a; Dias et al., 2013; Yan et al., 2013), AD (Butterfield et al., 2002; Yan et al., 2013; Hroudova et al., 2014; Zuo et al., 2015) and ALS (Beal et al., 1997; Pedersen et al., 1998). Moreover, ROS-dependent enhanced oxidative alterations of proteins such as $\alpha$-synuclein in $\mathrm{PD}, \beta$-amyloid $(\mathrm{A} \beta)$ and tau in AD and SOD 1 in ALS may also potentiate protein misfolding and reduce degradation. Thus, the ROS-dependent changes in protein metabolism increase insoluble aggregates or accumulation of protofibrils under pathological conditions, ultimately contributing to neurodegeneration (Giasson et al., 2000b; Horiguchi et al., 2003). Even in the absence of oxidative stress, some proteins possess the potential to cause toxicity leading to cell death. Proteins have to reach a singular tridimensional structure by a complex folding pathway aiming to be functionally active, which is determined by the primary amino acid sequence and the subcellular environment (Anfinsen, 1973). Proteins that are not able to attain the native state are identified as misfolded and targeted by two degradation pathways: molecular chaperones or the UPS (Herczenik and Gebbink, 2008). Damage in the UPS may be caused by the misfolded protein accumulation in the endoplasmic reticulum or failure of the enzymes that belong to the ubiquitin conjugation and deconjugation pathway. As a consequence, damaged USP leads to the accumulation of protein aggregates inside the cell (Berke and Paulson, 2003). Besides, misfolded protein can also be secreted into the extracellular space, leading to the development of extracellular plaques (Friedrich et al., 2010). Formation of oligomers and aggregates occur when a critical concentration of misfolded protein is attained. Depending on the neurodegenerative disease in question, there may be accumulation of aggregated proteins, both inside and outside the cell. This aggregation can generate deleterious cell effects. All the major neurodegenerative diseases including AD, PD and $\mathrm{HD}$ are also known as protein misfolding disorders and they show similarities regarding protein aggregation. For instance, high levels of amyloid $\beta$ can be observed in the brain of individuals with AD (Glenner and Wong, 1984), $\alpha$-synuclein in PD (Polymeropoulos et al., 1997), and huntingtin in the case of HD (Davies et al., 1997; DiFiglia et al., 1997). However, although it is clear that the type of protein that forms the aggregates are different in each of these neurodegenerative diseases, the most common consequent abnormality is synaptic dysfunction, characterized by dendritic spine loss and reduced post synaptic density, leading to disturbance of network connections and cell 
death (Selkoe, 2002; Picconi et al., 2012; Sepers and Raymond, 2014).

Using model organisms, such as Caenorhabditis elegans, it has been suggested that, as we age, our body progressively loses some mechanisms related to the prevention of accumulation of erroneously folded proteins (Kirstein-Miles and Morimoto, 2010). Corroborating this hypothesis, in the autopsied brain of elderly, the presence of amyloid plaques, NFTs, Lewy bodies, synaptic dystrophy, neuronal loss and decreased brain volume are consistent findings, even though these individuals were not diagnosed with any neurological disease (Elobeid et al., 2016). Therefore, the boundary between pathological neurodegeneration findings and normal aging alterations is not yet clear. Actually, it is unequivocally accepted that aging causes neurodegeneration. Aging is associated with various processes, including loss of protein homeostasis that leads to the development of aggregates and inclusion bodies, DNA damage, lysosomal dysfunction, epigenetic changes and immune dysregulation. These processes, which are consequences of the interaction between genetic predisposition of an individual and his/her exposure to the environment, determine the incidence and prevalence of neurodegeneration, probably in a cell-specific manner. As a consequence, several diseases might develop in accordance with the spatiotemporal distribution of the lesions (Herskind et al., 1996; Brunk and Terman, 2002; Hernandez et al., 2011). The characterization of all the genetic interactions might result in new therapeutic possibilities aiming to modulate both the aging process and age-associated diseases (Johnson et al., 2015; Lardenoije et al., 2015). However, the cause of most neurodegenerative diseases cannot be clearly demonstrated and appear to be sporadic in most cases, posing difficulties for the development of genetic therapies.

Despite all the knowledge acquired so far, regardless of the type or cause of cell death, there are no disease-modifying drugs to treat neurodegenerative diseases. Neuronal cell death occurs as a result of a series of deleterious events not yet fully understood. Knowledge of more mechanisms that underlie neurodegeneration may help the development of alternatives to abort the damage.

\section{ANIMAL TOXINS TO TREAT NEURODEGENERATIVE DISEASES}

\section{Alzheimer's Disease}

First described more than 100 years ago by the German scientist Alois Alzheimer, $\mathrm{AD}$ is the most prevalent neurodegenerative disease and the leading cause of dementia (Alzheimer, 1907). More than 24 million people in the world exhibit some form of dementia and this number is predicted to double in 20 years (Ferri et al., 2005). AD is the cause of $60-80 \%$ of dementia cases and mostly affects people over 65 years of age, leading to death in about 7-10 years of symptoms onset (Plassman et al., 2007). $\mathrm{AD}$ is characterized by severe brain atrophy and progressive neuronal death, affecting cognitive brain areas and leading to severe memory impairments, behavioral changes, language and speaking impairment, attention deficits and overall cognitive decline (Johnson et al., 2008; Holtzman et al., 2011). AD has many etiological factors and, in most cases, reliable diagnostics can only be obtained post-mortem (Castellani et al., 2010). A meta-analysis study showed that $9 \%$ of individuals assessed for dementia are in fact suffering from other treatable conditions, such as depression, delirium, side effects from drugs, drug abuse, thyroid dysfunction and vitamin deficiency (Clarfield, 2003). Likewise, many of $\mathrm{AD}$ features, such as plaques and tangles, can also be observed in the post mortem brain of individuals that do not exhibit dementia (Elobeid et al., 2016). Also, the differences between $\mathrm{AD}$ induced cognitive decline and normal aging cognitive changes can be very subtle, making it difficult to establish an early disease diagnosis. The vast majority of $\mathrm{AD}$ symptomatic cases (99\%) begins after 65 years of age and are referred as late onset or sporadic AD (Holtzman et al., 2011). Although genetic factors may contribute to the risk of developing late onset $\mathrm{AD}$, distinctions can be made between sporadic $\mathrm{AD}$ cases and early onset familial AD. Some of the first insights for understanding $\mathrm{AD}$ pathogenesis came from the study of familial AD. Familial AD accounts for a small percentage of cases, $\sim 1 \%$, and is transferred from one generation to the next as an autosomal dominant heritage (Guerreiro et al., 2012). Mutations on the genes encoding for APP (Goate et al., 1991), Presenilin-1 (PS1) (Sherrington et al., 1995) and Presenilin-2 (PS2) (LevyLahad et al., 1995; Rogaev et al., 1995) are the cause of most familial cases of $\mathrm{AD}$, with the onset of symptoms occurring between 30 and 60 years of age. Despite the well characterized mutations that lead to familial $\mathrm{AD}$, as mentioned previously, most AD cases are sporadic. Several risk factors have been shown to contribute to non-familial $\mathrm{AD}$, including aging (Ferri et al., 2005), lack of cognitive reserve (Roe et al., 2007), diminished physical activity (Podewils et al., 2005), smoking habit (Anstey et al., 2007), obesity (Lee, 2011) and diabetes (Biessels et al., 2006).

At the cellular level, the major hallmarks of $\mathrm{AD}$ are the formation of $A \beta$ plaques and NFTs of hyperphosphorylated tau protein that can be observed specially in the basal forebrain, frontal lobe, hippocampus and cerebral cortex of both human cases and animal models (Duyckaerts et al., 2009; De-Paula et al., 2012; Taipa et al., 2012; Armstrong, 2014; Garin et al., 2015). However, no strict correlation has been found regarding the number of plaques and $\mathrm{AD}$ cognitive decline, although synaptic loss is pointed as the major correlate of cognitive impairment (Terry et al., 1991). NFTs are intracellular structures composed of hyperphosphorylated tau protein, a microtubule-associated protein that normally binds tubulin and stabilize microtubules, but that dissociates from tubulin and tends to self-aggregate when it is hyperphosphorylated (Kidd, 1963; Anderton et al., 1987). Oxidative stress, mitochondrial dysfunction, excitotoxicity, neuroinflammation and impaired cholinergic transmission are also key pathological features of the disease (Coyle et al., 1983; Hynd et al., 2004; Moreira et al., 2007; Rojo et al., 2008). As many of these features also overlap with other disorders and occur in healthy individuals, developing accurate biomarkers and models for the disease is a challenging task. The great majority of $\mathrm{AD}$ animal models are based on transgenic animals, especially mice. Therefore, the lack of a 
robust sporadic $\mathrm{AD}$ animal model is probably a major pitfall delaying the development of disease-modifying drugs.

Currently, Memantine, an NMDA receptor antagonist that aims to reduce neuronal death triggered by excitotoxicity, and other four different inhibitors of acetylcholinesterase (AChE) that slightly ameliorates AD's cholinergic deficits, are the only drugs to treat $\mathrm{AD}$ patients that is approved by the United States Food and Drug Administration (FDA). Still, none of these drugs delay disease progression. The development of novel molecules targeting different aspects of AD pathology through the use of natural toxins could be a promising approach, taking advantage of these toxins selectivity for different enzymes, channels and subunits (Table $\mathbf{1}$ ).

Snake-venom-derived toxins have been widely investigated for potential therapeutic applications in $\mathrm{AD}$ and other pathologies. These venoms are mainly divided in two groups: neurotoxins and dendrotoxins. The dendrotoxins are isolated from the African mambas (Dendroaspis genus), some of which are best known to act as potassium channels blockers (Koh et al., 2006). Displaying much lower toxicity than the other components of Dendroaspis angusticeps (green mamba) venom, the fasciculins are known to inhibit AChE activity through binding to a peripheral site of this enzyme, potentiating acetylcholine action and producing generalized muscle fasciculation (Mebs, 1989). Therefore, these toxins could be useful to relief acetylcholine deficits in disorders such as AD. Some efforts have been made in order to determine fasciculin-AChE complex structure and help the design of novel molecules with AChE inhibitory activity. Recent results from bioinformatics modeling revealed similar toxins with AChE potential inhibitory activity, supporting green mamba fasciculins as candidates for the development of AChE inhibitors to be used in AD (Harel et al., 1995; Waqar and Batool, 2015).

The Indian viper Daboia russelli russelli produces a venom containing abundant $\mathrm{PLA}_{2}$ isoforms, procoagulant enzymes (factor $\mathrm{X}$ and $\mathrm{V}$ activators) haemorragins, nucleases, proteases, hyaluronidases and several other compounds (Tsai et al., 1996).
A recent study has demonstrated that the factor $\mathrm{V}$ (RVV-V) component destabilizes $\mathrm{A} \beta$ aggregates on in vitro cultures of human SH-SY5Y cells incubated with $A \beta_{42} / A \beta_{40}$ peptides (Bhattacharjee and Bhattacharyya, 2013). The compound also protected cells against $A \beta$-induced toxicity. Further investigations discarded proteolysis as a mechanism for this effect, indicating an $A \beta$ aggregate destabilizing activity. Using RVV-V as a template, novel small peptides were synthesized, retaining anti-A $\beta$-aggregating activity. Moreover, it was reported that one of the peptides has a half-life of $24 \mathrm{~h}$ (Bhattacharjee and Bhattacharyya, 2013). Although other previous antiaggregation molecules have been validated in animal models but failed to progress toward clinical use, subsequent studies employing these peptides could hold potential as novel therapeutic tools (Van Dam and De Deyn, 2006).

Metalloproteases have an important role in regulating many physiological processes. ECE1 and NEP are two metalloproteases whose activity degrade $A \beta$ in the brain (Nalivaeva et al., 2012). Different inhibitors of these enzymes have been used several times for different purposes (Lin et al., 2006; Smollich et al., 2007), although stimulators of their activity are much harder to find, except for a few compounds tested in vitro, such as green tea polyphenols (Ayoub and Melzig, 2006) and kynurenic acid (Klein et al., 2013). Enhanced ECE1 and NEP activities are thought to have beneficial effects against $\mathrm{AD}$ pathology as demonstrated by genetically induced increased expression of ECE1 and NEP on the APP (Choi et al., 2006) and APP/PS1 transgenic mouse models of AD (El-Amouri et al., 2008). A recent study identified the peptide K-49-P1-20 contained in the structure of myotoxin II, a $\mathrm{PLA}_{2}$ present in the venom of another viper: Bothrops asper. The synthetic peptide was effective to stimulate ECE-1 and NEP activities on the bradykinin-based quenched fluorescent substrate assay, probably via positive allosteric regulation (Smith et al., 2016). Moreover, results from liquid chromatographymass spectrometry analysis indicates that ECE-1 cleavage of endogenous $A \beta 40$ present in the cerebrospinal fluid obtained

TABLE 1 | Animal toxins to treat Alzheimer's disease.

\begin{tabular}{|c|c|c|c|c|}
\hline Toxin/Substance & Species of origin & Effects & Experimental model & Reference \\
\hline Fasciculins & Dendroaspis (snake) & Inhibits AChE & Bioinformatics modeling & $\begin{array}{l}\text { Mebs, 1989; Harel et al., 1995; } \\
\text { Waqar and Batool, } 2015\end{array}$ \\
\hline RW-V & $\begin{array}{l}\text { Daboia russeli russeli } \\
\text { (viper) }\end{array}$ & Reduces $A \beta$ plaque deposition & SH-SY5Y cell culture & $\begin{array}{l}\text { Bhattacharjee and } \\
\text { Bhattacharyya, } 2013\end{array}$ \\
\hline $\begin{array}{l}\text { K-49-P1-20 peptide } \\
\text { (isolated from Myotoxin } \\
\text { II } P L A_{2} \text { ) }\end{array}$ & Bothrops asper (viper) & $\begin{array}{l}\text { Enhances ECE-1 and NEP } \\
\text { activities promoting } A \beta \\
\text { clearance }\end{array}$ & HEK293 cell culture & $\begin{array}{l}\text { El-Amouri et al., 2008; } \\
\text { Smith et al., } 2016\end{array}$ \\
\hline SVHRP & $\begin{array}{l}\text { Buthus martensii } \\
\text { karsch (scorpion) }\end{array}$ & $\begin{array}{l}\text { Increases BDNF levels and } \\
\text { neurogenesis } \\
\text { Anti-inflammatory } \\
\text { Reduces A } \beta \text { plaques }\end{array}$ & $\begin{array}{l}\text { Caenorhabditis elegans CL4176, } \\
\text { CL2006, Cl2355 strains }\end{array}$ & $\begin{array}{l}\text { Wang et al., 2014; } \\
\text { Zhang et al., } 2016\end{array}$ \\
\hline $\begin{array}{l}\text { PhTx3-1 } \\
\text { PhTx4-5-5 }\end{array}$ & $\begin{array}{l}\text { Phoneutria nigriventer } \\
\text { (spider) }\end{array}$ & $\begin{array}{l}\text { Memory improvement } \\
\text { Neuroprotective }\end{array}$ & $\begin{array}{l}\text { Mice i.c.v. A } \beta \text { administration } \\
\text { Hippocampal slices ODLG model } \\
\text { Primary corticostriatal neuronal } \\
\text { culture }\end{array}$ & $\begin{array}{l}\text { Gomes et al., 2013; } \\
\text { Silva et al., } 2016\end{array}$ \\
\hline $\mathrm{BVPLA}_{2}$ & $\begin{array}{l}\text { Apis mellifera } \\
\text { (Honey bee) }\end{array}$ & $\begin{array}{l}\text { Reduces } A \beta \text { plaque deposition } \\
\text { Cognitive improvement } \\
\text { Anti-inflammatory }\end{array}$ & $3 \times T g-A D$ mice & Ye et al., 2016b \\
\hline
\end{tabular}


from a subject with $\mathrm{AD}$ is increased in the presence of K-49-P120 peptides, further confirming a potential role for management of $\mathrm{A} \beta$ in $\mathrm{AD}$ (Smith et al., 2016).

Scorpion toxins are another group of animal toxins with potential therapeutic applications. The Buthus martensii karsch (Bmk) scorpion venom has been used in Chinese medicine for the treatment of nervous system disorders for 1000s of years (Wang et al., 2009). Increased neurogenesis, neuron maturation and expression of brain derived neurotrophic factor (BDNF) are reported after treating cultures of neural stem cells with the SVHRP (Wang et al., 2014). Moreover, anti-inflammatory effects of Bmk extracts have also been reported when tested in human chondrocyte and macrophage cultures (Kim et al., 2005). These evidences support a possible role of Bmk venom components such as SVHRP for targeting other neurodegenerative diseases such as AD. Subsequent research provided positive results regarding SVHRP therapeutic use in $\mathrm{AD}$, using the transgenic Caenorhabditis elegans $\mathrm{A} \beta$-expressing model (Zhang et al., 2016). Dose-dependent improvements related to reduced oxidative stress, reduced $A \beta$ plaque deposition and $A \beta$-induced toxicity were observed following SVHRP treatment, indicating that this compound has potential therapeutic effects.

The venom obtained from spiders, wasps and bees have also been the subject of many studies. Even though spiders are one of the largest group of venomous animals with approximately 37,000 species, a very small fraction of spider toxins have been characterized so far (Escoubas and Bosmans, 2007). Most of the studies have investigated spider venom toxins for therapeutic applications against cancer, cardiovascular diseases and mostly for analgesic and antinociceptive effects (Pineda et al., 2014). However, there are few studies investigating potential uses of spider toxins in neurodegenerative disorders. Spider venoms contains inorganic ions, free acids and amino acids, glucose, biogenic amines, neurotransmitters and larger protein toxins, and, so far, their main targets are $\mathrm{K}^{+}, \mathrm{Ca}^{2+}$ and $\mathrm{Na}^{+}$channels (Escoubas et al., 2000b). The venom of the Brazilian spider Phoneutria nigriventer has been widely studied since the first reports concerning the isolation of different fractions containing several types of toxins. The PhTx3-1 toxin was shown to reduce memory-deficits induced by i.c.v. administration of $\mathrm{A} \beta_{25-35}$ in Swiss mice, an effect probably attributed to blockage of transient outward potassium currents (Figure 1) (Gomes et al., 2013). Furthermore, a recently published study described a toxin also isolated from Phoneutria nigriventer, $\mathrm{PhKv}$, that was able to induce antinociception by inhibition of AChE via intrathecal administration in mice (Rigo et al., 2017). Further studies will be important to demonstrate whether $\mathrm{PhKv}$ anti-AChE activity could be beneficial in AD. Another Phoneutria toxin, PhTx4-5-5, showed neuroprotective activity against $A \beta$ and glutamate-induced excitotoxicity by blockage of NMDA receptors in mice corticostriatal neuronal cultures (Figure 1) (Silva et al., 2016). Glutamate excitotoxicity is regarded as an important cell death trigger not only in $\mathrm{AD}$, but also in other neurodegenerative diseases such as HD. Corroborating the hypothesis that Phoneutria nigriventer toxins are also valid therapeutic options to treat $\mathrm{HD}, \mathrm{PhTx} 4-5-5$ was shown to protect corticostriatal neuronal cultures obtained from a mouse model of $\mathrm{HD}$, the BACHD mice (Silva et al., 2016).

The hymenoptera order of insects comprises all species capable of stinging such as bees, wasps and ants. The most studied venoms are those from the Apis genus which contain a variety of active components such as peptides (e.g., melittin, apamin), enzymes (e.g., $\mathrm{PLA}_{2}$ and hyaluronidases), biogenic amines and others (Son et al., 2007; Matysiak et al., 2011). There are several proposed mechanisms of action for bee venom $(\mathrm{BV})$ and its composing toxins regarding its different therapeutic applications. For instance, BV has anti-inflammatory, antiapoptotic, antioxidative, and antiglutamate induced toxicity actions and is also capable of restoring normal neurotransmitter signaling (Awad et al., 2017). The use of BV to treat dementia-related disorders has been investigated. Lower levels of proinflammatory molecules and increased levels of pERK and BDNF have been observed following BV treatment of an animal model of vascular dementia induced by bilateral common carotid artery occlusion (Cai et al., 2016). LPS intra peritoneal (i.p.) administration induced $\mathrm{A} \beta$ accumulation, neuroinflammation and memory loss on male imprinting control region mice ( $\mathrm{Gu}$ et al., 2015). Administration of BV i.p. inhibited LPSinduced amyloidogenesis, neuroinflammation and memory loss by inhibiting the NF- $\kappa$ B pathway (Gu et al., 2015). More recently, it has been demonstrated that 6 months weekly treatment of $3 \mathrm{xTg}-\mathrm{AD}$ mice with $\mathrm{BV}$ derived $\mathrm{PLA}_{2}\left(\mathrm{BVPLA}_{2}\right)$ evoked dramatic reductions of the $A \beta$ deposits in the hippocampus with enhancement of cognitive function (Ye et al., 2016b). Elevated glucose metabolism, reduced microglial activation and $\mathrm{CD} 4^{+}$ $\mathrm{T}$ cell infiltration were also other positive outcomes reported in this study. Furthermore, BVPLA 2 was at least as effective as Donepezil (a FDA AD approved drug) in ameliorating cognitive and inflammatory processes with lesser adverse effects such as weight loss (Ye et al., 2016b). Indeed, as discussed earlier, PLA 2 are key enzymes targeting inflammatory associated processes and many authors have also proposed a focus on BVPLA $_{2}$ therapeutic potential (Chung et al., 2015; Lee and Bae, 2016). The expectation is that further research will provide deeper understanding of BV components and mechanisms underlying their therapeutic effects. So far, the observed anti-inflammatory, neuroprotective and antiaggregate activities support the place of BV components as potential tools for treating neurodegeneration.

\section{Parkinson's Disease}

Parkinson's disease is the second most prevalent neurodegenerative disease, mainly affecting people over the age of 55. PD is characterized by progressive neurodegeneration in the substantia nigra pars compacta $(\mathrm{SNpc})$, affecting mainly dopaminergic neurons. Moreover, cytoplasmic inclusions called Lewis bodies are observed in the brain of individuals with PD (Lang and Lozano, 1998). Neurodegeneration is the direct cause of PD symptoms, which include bradykinesia, resting tremor and rigidity (Dauer and Przedborski, 2003; George et al., 2009). In addition to these motor alterations, individuals with PD may also exhibit cognitive impairment and psychiatric disturbance (Beitz, 2014). When more than 50\% of the SNpc neurons die, the clinical symptoms become evident (Marsden, 1990; 


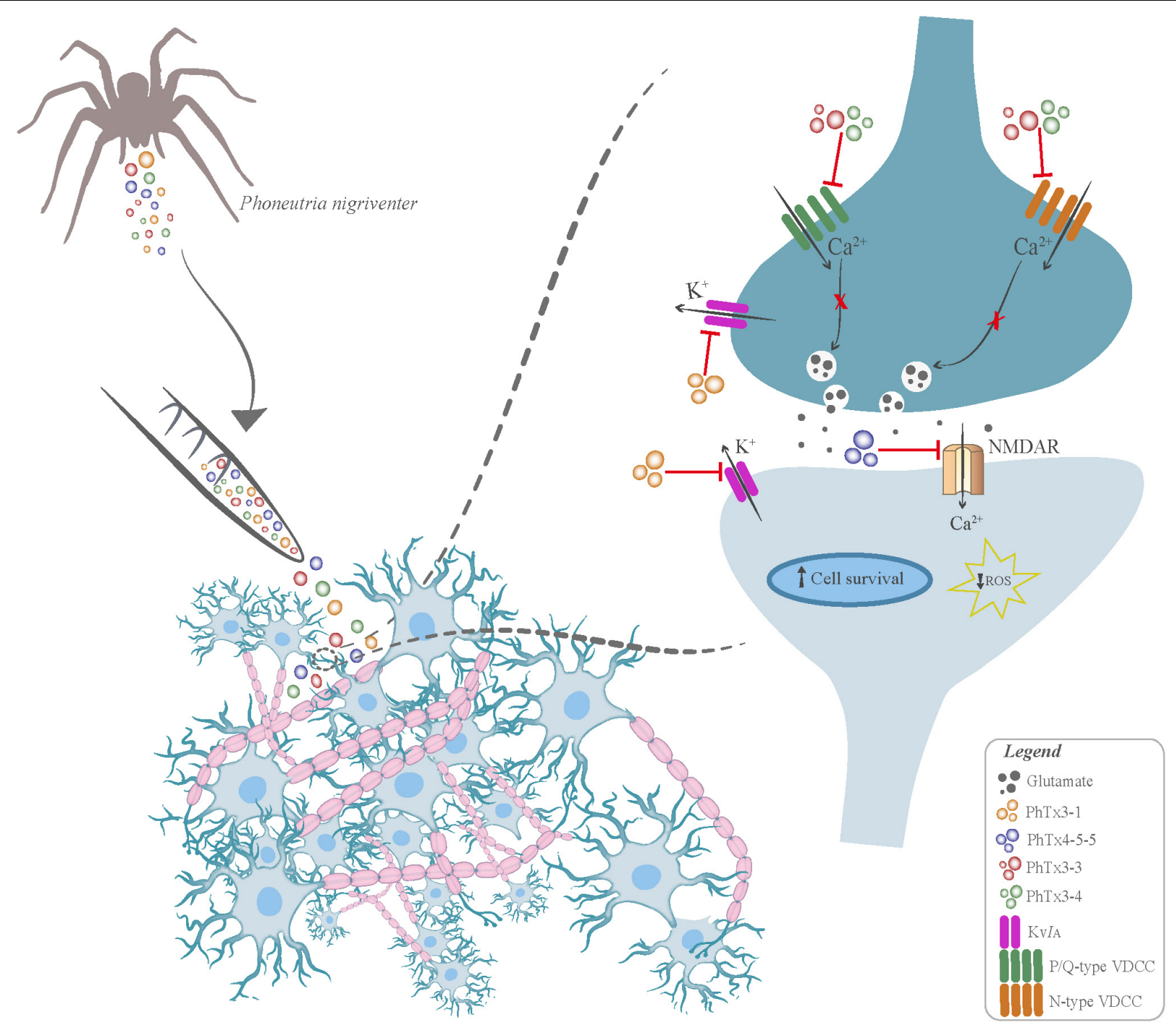

FIGURE 1 | Neuroprotective mechanisms elicited by Phoneutria nigriventer venom. The venom of the spider Phoneutria nigriventer contains a mixture of toxins that affect ion channel function, decreasing neuronal cell death and ameliorating neurotransmission alterations. The PhTx3-1 toxin is capable of blocking transient outward $\mathrm{K}^{+}$currents $(\mathrm{Kv} / \mathrm{A})$, improving behavioral parameters associated with memory. The PhTx4-5-5 toxin has neuroprotective activity against glutamate-induced excitotoxicity by blocking NMDA receptors. The PhTx3-3 and PhTx3-4 toxins block N- and P/Q-type voltage-dependent $\mathrm{Ca}^{2+}$ channels (VDCC), thus inhibiting $\mathrm{Ca}^{2+}$ influx, glutamate release and ROS formation.

Ross et al., 2004). As in the case of AD, PD can be sporadic or hereditary. Notably, familial PD accounts for only $10 \%$ of the cases. In addition to genetic predisposition, several other factors contribute to disease pathology, including age-related alterations and environmental toxins (Castrioto et al., 2014). Moreover, only rare cases of familial PD are caused by the mutation of a single gene. Mutations in about 13 PD genes have already been linked to the pathogenesis (Kumar et al., 2012). The genes that are mutated in PD encode proteins that have been shown to play an important role in the disease, including $\alpha$-synuclein. The presence of toxic aggregated forms of $\alpha$-synuclein is regarded as a main factor contributing to pathology and having a critical role in microglia-mediated neuroinflammation (Polymeropoulos et al., 1997; Mhyre et al., 2012). In fact, more recently, it has become more evident the central role of chronic inflammation and glial activation as crucial factors inducing the dopaminergic neurodegeneration underlying PD pathogenesis (Loeffler et al., 1994; Cicchetti et al., 2002; Ghosh et al., 2007; McGeer and McGeer, 2008; Hirsch and Hunot, 2009; Qian et al., 2010).

The gold standard therapy for PD patients consists of a combination of carbidopa and levodopa. Levodopa helps to reestablish dopamine levels in the striatum and is effective in reducing motor impairment and disability, whereas carbidopa inhibits the peripheral metabolism of levodopa, thereby allowing its therapeutic concentrations to be achieved in the brain without disabling peripheral adverse effects (Miyasaki et al., 2002; Gazewood et al., 2013). This treatment is usually started when patients begin to experience functional impairment. Although 
the discovery of levodopa revolutionized PD treatment, after 5 years of therapy, $50 \%$ of patients experience motor response complications, associated with involuntary movements called dyskinesias, which are difficult to control and significantly impair quality of life (Miyasaki et al., 2002; Stowe et al., 2008). The alternative treatment consists of dopamine agonists, MAO-B inhibitors and catechol O-methyltransferase inhibitors, which improve motor symptoms and functional status, but are less effective than levodopa and also generate an increase in dyskinesias (Stowe et al., 2008; Stathis et al., 2015). Nevertheless, there are no disease-modifying drugs to treat PD patients and most current treatments are symptomatic and none delay dopaminergic neuron degeneration. The ideal approach to treat PD patients should prevent dopaminergic neuronal cell loss and, thereby, slows or even halts disease progression.

Molecules from BV are currently under investigation as neuroprotective tools to treat PD. It has been shown that chronic release of proinflammatory cytokines by activated astrocytes and microglia exacerbates dopaminergic neuron degeneration in PD. These findings corroborate the hypothesis that inflammatory processes are potential interventional targets in $\mathrm{PD}$ and other neurodegenerative diseases (Teismann and Schulz, 2004; Wang et al., 2015). Recent studies suggest that BV could lessen PDrelated neuroinflammation (Figure 2). One of the first studies indicating BV therapeutic potential in PD showed that BV injection suppresses neuroinflammatory responses in an MPTPinduced mouse model of PD (Kim et al., 2011). MPTP-induced mouse is the most widely used animal model to study this disease. Administration of MPTP to mice leads to dopaminergic cell death in the SNpc and induces a severe and irreversible PD-like syndrome (Przedborski and Vila, 2003; Meredith and Rademacher, 2011). Increased number of activated microglia is also observed in the SNpc and striatum of this mouse model, contributing to secondary dopaminergic PD neuronal cell loss (McGeer et al., 1988, 2003; McGeer and McGeer, 2008). In this study, BV was subcutaneously administered into the acupuncture point in mice (Kim et al., 2011), the most commonly used method for applying BV (Ezzo et al., 2001; Lee et al., 2008; Kim and Jeon, 2014). Acupuncture is a technique used to treat certain illness through stimulation of specific anatomical points using needles, laser or small electrical currents (Lao et al., 2003). A previous study showed that $\mathrm{BV}$ acupuncture pretreatment effectively protects dopaminergic neurons against MPTP toxicity by inhibiting Jun activation (Doo et al., 2010). BV reduces microglial activation, which is evidenced by decreased MAC-1 levels, a microglia activation marker, and iNOS expression in the SNpc (Kim et al., 2011). Thus, this study suggests that the dopaminergic neuroprotective effect elicited by BV treatment of MPTP PD model appears to be mainly due to a decrease in neuroinflammation via the suppression of proinflammatory factors, such as cyclooxygenase-2 and PLA , tumor necrosis factor- $\alpha$ (TNF- $\alpha$ ) and interleukin-1 (IL-1) (Kim et al., 2011). Consistent with these results, other studies have shown that BV treatment reduces microglial activation and the infiltration of CD4 T effector cells into the SNpc (Chung et al., 2012, 2015; Ye et al., 2016a). Additionally, BV treatment significantly increases the proportion of regulatory $\mathrm{T}$ cells
(T reg) in vivo and in vitro and $\mathrm{T}$ reg depletion abrogates the neuroprotective effects of BV (Chung et al., 2012). T regs play an important role in the regulation of the immune response of peripheral CD4 $\mathrm{T}$ cells, thus being a crucial step in the maintenance of tolerance in healthy conditions (Sakaguchi et al., 2008). In addition, adoptive transfer of $T$ regs to MPTPtreated mice prevents PD-related neuronal degeneration through attenuation of microglial activation and neuroinflammatory responses (Reynolds et al., 2007). Therefore, these studies suggest that the neuroprotective effects of BV treatment are mediated in part by the modulation of the adaptive immune response by increasing the proportion of functional $\mathrm{T}$ regs (Chung et al., 2012). Subsequently, the same research group demonstrated that BVPLA $_{2}$, the major BV compound, is capable of inducing $\mathrm{T}$ reg expansion, promoting survival of dopaminergic neurons. The results also showed that $\mathrm{BVPLA}_{2}$ directly binds to mannose receptor on dendritic cells and, consequently, promotes secretion of PGE2, which results in Treg differentiation in the MPTP model of PD (Chung et al., 2015) (Figure 2).

BVPLA $_{2}$ has a wide variety of pharmacological properties, including anti-HIV activity, myotoxicity and neurite outgrowth induction (Fenard et al., 2001; Nakashima et al., 2004). Moreover, in a human A53T $\alpha$-Syn mutant transgenic mice (A53T $\mathrm{Tg}$ ) the expression of $\alpha$-synuclein was reduced, as well as microgliosis in spinal cord and the M1/M2 ratio through the treatment with BVPLA 2 (Ye et al., 2016a). It has been shown that the phenotype of activated microglia (M1/M2) controls the repair and regeneration response following nerve injury (Kigerl et al., 2009; David and Kroner, 2011). Several studies classify microglia into two different polarizations: M1 and M2. The first is related to proinflammatory action and release of cytokines such as TNF- $\alpha$. On the other hand, M2 is important for homeostasis, with anti-inflammatory action and producing cytokines such as IL-10 (Orihuela et al., 2016; Tang and Le, 2016). However, several other studies show opposite results and do not support this notion that M1 is pro and M2 is anti-inflammatory (Gautier et al., 2012; Miller et al., 2012). At the behavioral level, BV treatment ameliorates motor coordination and balance of $\mathrm{A} 53 \mathrm{~T} \mathrm{Tg}$ mice in a modified pole test (Ye et al., 2016a). Previous studies have also shown the beneficial actions of BV treatment on the pathological functioning of the circuits underlying motor PD symptoms (Maurice et al., 2015; Kim et al., 2016). Therefore, these findings suggest that $\mathrm{BVPLA}_{2}$ is a relevant pharmacological tool in PD.

Another specific component of BV, apamin, was also studied in isolation. Previous studies reported that the peptide apamin protects cultured mesencephalic dopaminergic neurons (Salthun-Lassalle et al., 2004; Toulorge et al., 2011). Employing the MPTP-induced PD model, which was exposed to either BV or apamin treatment via intraperitoneal injections, it was possible to observe that the BV protective effect is not restricted to acupoint stimulation. High doses of the BV peptide apamin lead to the same level of protection of the cellular bodies of dopaminergic neurons and also diminish inflammatory cytokines, which can be deleterious. However, this protection cannot be seen at the axonal level when only apamin is used, whereas BV grants safety 


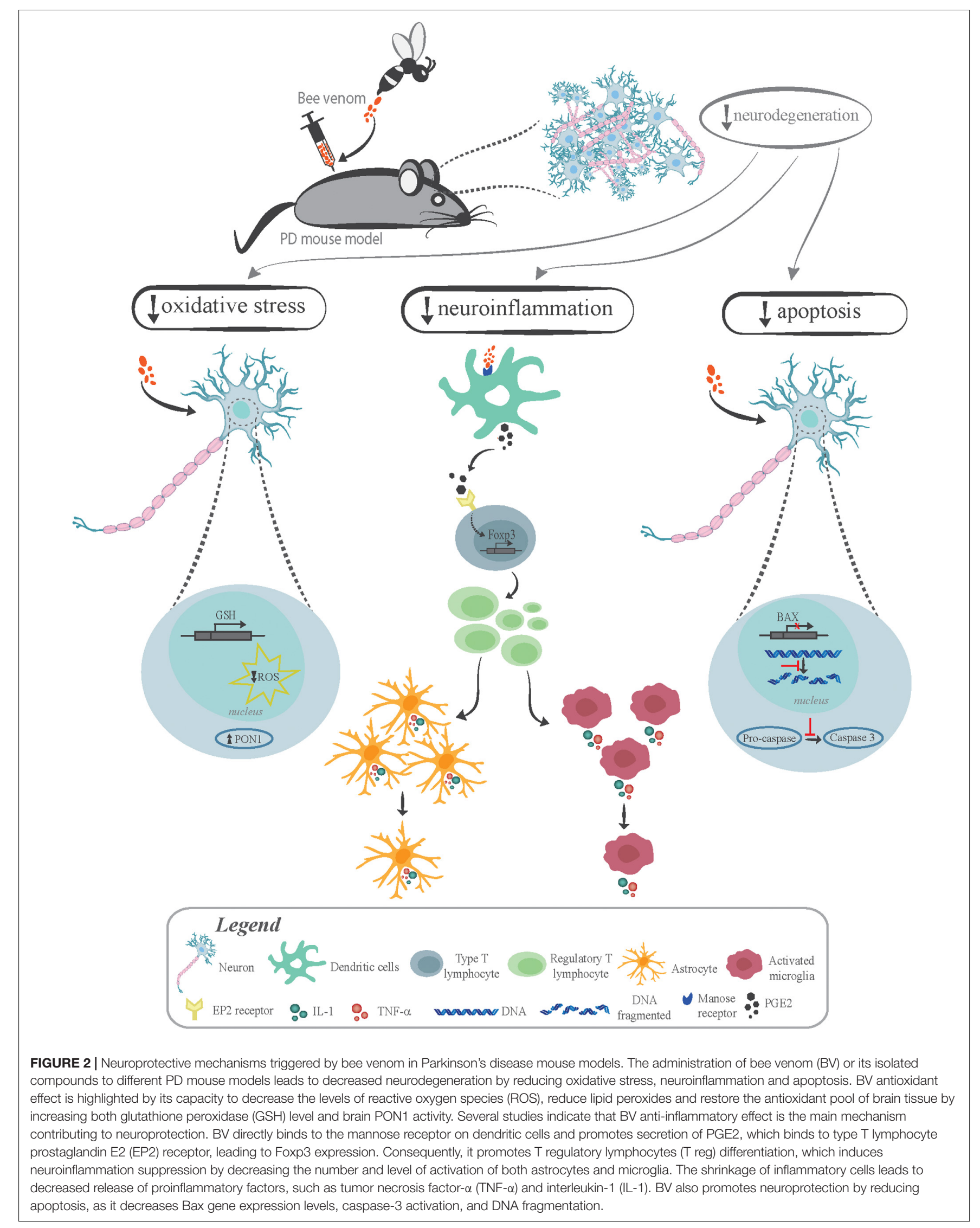


of this site, suggesting that other molecules might be involved in the axonal protection phenomena (Alvarez-Fischer et al., 2013).

Interestingly, a study compared the neuroprotective effect of BV and Pramipexole on the progressive neuronal damage and motor dysfunctions observed in a subchronic MPTP mouse model of PD. Pramipexole is a potent and selective D3 dopamine receptor agonist that is clinically important for managing early stage PD (Mierau and Schingnitz, 1992; Bennett and Piercey, 1999). Furthermore, Pramipexole has been shown to exert a neuroprotective effect against MPTP-induced damage to the nigrostriatal dopamine system in mice (Anderson et al., 2001). Significant astrocytic activation is observed following MPTP subchronic administration and both BV and Pramipexole effectively reduce activation of astrocytes in SNpc, decreasing death of dopaminergic neurons. Moreover, both BV and Pramipexole ameliorate motor deficits, whereas, in primary cultured astrocytes, only BV reduces $\mathrm{MPP}+$-induced astroglial activation. Taken together, these observations suggest that both BV and Pramipexole effectively reduce $\mathrm{PD}$-associated pathologies and thus the neuroprotective effects of BV are associated with reduced astrocytic activation (Kim et al., 2016).

The neuroprotective effect of BV acupuncture therapy was also evaluated in neurodegeneration induced by rotenone. Rotenone, a natural insecticide, is extremely lipophilic and easily crosses the blood-brain barrier (BBB) (Talpade et al., 2000). A Parkinsonism rat model can be created by chronic exposure to rotenone leading to motor deficits and dopaminergic neuronal loss (Deng et al., 2010). This study further indicates that BV therapy has a neuroprotective effect that is mediated through inhibition of neuroinflammation, oxidative stress and apoptosis. BV powerful antioxidant effect is highlighted by its capacity to reduce lipid peroxides and restore the antioxidant pool of brain tissue by increasing both glutathione peroxidase level and brain paraoxonase-1 (PON1) activity, preventing neuronal injury. BV also decreases Bax gene expression levels and suppresses apoptotic pathways, which is further demonstrated by decreased DNA fragmentation and suppressed caspase- 3 activation induced by rotenone (Khalil et al., 2015) (Figure 2).

Based on all these findings, clinical studies were performed to test whether $\mathrm{BV}$ could provide an effective option to treat neurodegenerative diseases, including PD (Mirshafiey, 2007). One of these studies explored the benefits of both acupuncture and bee venom acupuncture as adjuvant therapies for idiopathic PD (Cho et al., 2012). Forty-three adults with idiopathic Parkinson's disease were recruited and assessed using the Unified Parkinson's Disease Rating Scale, the Parkinson's Disease Quality of Life Questionnaire, the Beck Depression Inventory, the Berg Balance Scale, and the time and number of steps required to walk $30 \mathrm{~m}$. Subjects were stimulated twice a week for 8 weeks. In this pilot study, both acupuncture and bee venom acupuncture showed promising results as adjuvant therapies for Parkinson's disease (Cho et al., 2012). In another monocentric double-blinded, randomized controlled pilot study, 40 PD cases were evaluated regarding the potential disease-modifying effects of BV monthly injections. The results obtained in this study indicate that BV treatment does not have any clear effect on PD symptomatology, but highlights the importance of further studies using higher doses and higher administration frequency of BV (Hartmann et al., 2016).

In addition to $\mathrm{BV}$, some other animal venoms are also being investigated as potential therapeutic strategies for PD treatment. For instance, it has been shown that the venom of the Chinese scorpion Bmk protects dopaminergic neurons in the SNpc and improves the related behavior deficits in PD models (Xu et al., 2015). At early stage PD, the scorpion venom peptide, SVHRP, protects against oxidative stress. The antioxidant actions and the protection of mitochondria by SVHRP were studied by using the 6-OHDA rat model for early PD (Yin et al., 2014). 6-OHDA is an oxidative stress neurotoxin that increases oxidative damage and decreases antioxidant ability in midbrain (Kirik et al., 1998). SVHRP was found to be successful in reversing the abnormal activities of MAO-B, SOD, and MDA in the mitochondria of neurons in the midbrain, and in improving the antioxidant ability in an early stage PD rat model (Yin et al., 2014). In addition, SVHRP preserves the function of axons and promotes up-regulation of Bax and down-regulation of Bcl-2 (Wang and Qin, 2010; Yin et al., 2014; Xu et al., 2015).

Snake venom has also been studied as a therapeutic tool to treat PD. The neuroprotective activity and ability to induce neuritogenesis of a peptide isolated from the Bothrops atrox venom fraction Ba-IV was investigated using PC12 cells treated with the dopaminergic neurotoxin MPP+. This peptide, which had its sequence identified as Glutamic acid-ValineTryptophan, is able to significantly reduce cell death and this protective effect is associated with decreased activity of two apoptotic proteases, caspase- 9 and caspase-3. In addition, neurites outgrowth was observed in this Parkinson's cellular model after peptide treatment, indicating that the underlying mechanism of protection might include a neurotrophic effect (Martins et al., 2015).

Considering all these evidences, it is clear the importance and the great potential of these animal venoms as prospective pharmacological tools to treat PD (Table 2).

\section{Brain Ischemia}

Ischemia is caused by deficient blood supply to tissues due to obstruction of the arterial flow. Most ischemic episodes are caused by thromboembolic or atherothrombotic vasoocclusive disease and the major risk factors are age, hereditary factors, tobacco smoking, hyperlipidemia, hypertension, physical inactivity, obesity, and diabetes mellitus (Kalogeris et al., 2012). Clinically, the most significant event is brain ischemia, as neuronal cells are more sensitive to reduction in blood supply due to their intense metabolic activity (Kristian, 2004). Brain ischemia is followed by irreversible damage already detectable at less than $20 \mathrm{~min}$ after the ischemic event and, in most cases, resulting in severe brain damage, which is the leading cause of death and long-term disability worldwide (Ordy et al., 1993). The primary consequence of brain ischemia is a reduction in energy substrates, including glucose and oxygen. Consequently, ATP synthesis through glycolysis and oxidative phosphorylation slows or even stops, promoting a rapid decline in cellular ATP levels (Silver et al., 1997). Furthermore, the interruption of oxidative phosphorylation causes an increase in the release of ROS 
TABLE 2 | Animal toxins to treat Parkinson's disease.

\begin{tabular}{|c|c|c|c|c|}
\hline Toxin/Substance & Species of origin & Effects & Experimental model & Reference \\
\hline Bee Venom & $\begin{array}{l}\text { Apis mellifera } \\
\text { (Honey bee) }\end{array}$ & $\begin{array}{l}\text { Anti-inflammatory } \\
\text { Reduces microglial activation and } \\
\text { CD4+ } \\
\text { T cells infiltration } \\
\text { Improves motor coordination and } \\
\text { balance } \\
\text { Reduces apoptotic markers } \\
\text { Reduces oxidative stress }\end{array}$ & $\begin{array}{l}\text { MPTP mouse model } \\
\text { A53T Tg mice } \\
\text { Rotenone-induced } \\
\text { parkinsonism model }\end{array}$ & $\begin{array}{l}\text { Doo et al., 2010; } \\
\text { Kim et al., 2011; } \\
\text { Chung et al., 2012, 2015; } \\
\text { Khalil et al., 2015 } \\
\text { Ye et al., 2016a }\end{array}$ \\
\hline $\mathrm{BVPLA}_{2}$ & $\begin{array}{l}\text { Apis mellifera } \\
\text { (Honey bee) }\end{array}$ & $\begin{array}{l}\text { Promotes T reg cells expansion } \\
\text { Neuroprotective for dopaminergic } \\
\text { neurons } \\
\text { Reduces } \alpha \text {-synuclein expression } \\
\text { Reduces activation of microglia and } \\
\text { macrophages }\end{array}$ & A53T Tg mice & $\begin{array}{l}\text { Chung et al., 2015; } \\
\text { Ye et al., 2016a; } \\
\text { Kim et al., } 2016\end{array}$ \\
\hline Apamin & $\begin{array}{l}\text { Apis mellifera } \\
\text { (Honey bee) }\end{array}$ & $\begin{array}{l}\text { Neuroprotective } \\
\text { Anti-inflammatory } \\
\text { Improves motor function }\end{array}$ & $\begin{array}{l}\text { Rat mesencephalic } \\
\text { dopaminergic neuronal culture } \\
\text { MPTP PD model }\end{array}$ & $\begin{array}{l}\text { Salthun-Lassalle et al., 2004; } \\
\text { Toulorge et al., 2011; } \\
\text { Alvarez-Fischer et al., } 2013\end{array}$ \\
\hline Bee Venom & $\begin{array}{l}\text { Apis mellifera } \\
\text { (Honey bee) }\end{array}$ & $\begin{array}{l}\text { Improves scores of Unified PD } \\
\text { Rating Scale, Berg Balance Scale } \\
\text { and } 30 \mathrm{~m} \text { walking time }\end{array}$ & Clinical Trial & $\begin{array}{l}\text { Cho et al., } 2012 \\
\text { Hartmann et al., } 2016\end{array}$ \\
\hline SVHRP & $\begin{array}{l}\text { Buthus martensii } \\
\text { karsch (scorpion) }\end{array}$ & $\begin{array}{l}\text { Antioxidant } \\
\text { Antiapoptotic } \\
\text { Neuroprotective for SNpc } \\
\text { dopaminergic neurons } \\
\text { Behavior improvements }\end{array}$ & 6-OHDA rat model & $\begin{array}{l}\text { Yin et al., 2014; } \\
\text { Xu et al., } 2015\end{array}$ \\
\hline $\begin{array}{l}\text { Tripeptide (Glutamic } \\
\text { acid-Valine-Tryptophan) }\end{array}$ & Bothrops atrox (snake) & $\begin{array}{l}\text { Antiapototic } \\
\text { Enhances neurite outgrowth }\end{array}$ & PC12 MPP+ in vitro model & Martins et al., 2015 \\
\hline
\end{tabular}

(Abramov et al., 2007). Finally, when respiration is inhibited but glycolysis persists, protons and lactate generated during glycolysis accumulate, causing rapid intracellular acidification (Silver et al., 1997). Thus, ischemia invariably causes depletion of cellular ATP, intracellular acidification and generation of ROS, triggering a sustained rise of glutamate extracellular concentration (Phillis et al., 1996). This cascade of events culminates in a large elevation of intracellular $\mathrm{Ca}^{2+}$ in neurons and astrocytes, which triggers the death of neurons (Schubert et al., 1994; Rossi et al., 2007).

Ischemia treatment consists in the use of thrombolytics, aiming to lyse the arterial thrombus to restore blood flow to poorly perfused areas (thrombolysis) and to reduce the intrinsic vulnerability of the brain tissue to ischemia. However, the ischemia-treatment time interval determines therapy success. The exposure to a short but severe ischemia delays cell death and affects only a reduced number of neurons, whereas when ischemia last for a long period of time, broader and more rapid cellular destruction is observed, resulting in either focal or global ischemia, with the last leading to death in most cases (Lipton, 1999). Although thrombolytics help the prognosis, treatment is still far from satisfactory, mainly due to the limited therapeutic time window of approximately $3 \mathrm{~h}$ and the potential side effect of intracranial hemorrhage. To date, no neuroprotective drug has proven to be effective in phase III clinical trial studies. In addition, the heterogeneity of the disease makes it difficult to draw conclusions from the different studies. Therefore, the search for efficient drugs is an urgent unmet need.
Compelling evidences indicate that increased extracellular glutamate levels and exacerbated cytosolic $\mathrm{Ca}^{2+}$ overload are the main causes of neuronal injury during cerebral ischemia (Choi, 1994; Wheeler et al., 1994; Choi, 1995). Thus, drugs able to block these two events constitute potentially effective pharmacological strategies against the harmful consequences of ischemia. Studies investigating several animal venoms revealed a large amount of toxins capable of specifically blocking different $\mathrm{Ca}^{2+}$ channels types (Uchitel, 1997). Among the venoms, the $\omega$-conotoxins from the venom of the fish-eating marine snail Conus magus deserve especial attention. One of the $\omega$-conotoxins is MVIIC, which is comprised of 26 amino acids and is a member of the $\mathrm{Ca}^{2+}$ channels blockers toxin family (Hillyard et al., 1992; Liu et al., 1996). In vitro studies evaluating cerebral and spinal cord ischemia demonstrated that MVIIC significantly reduces $\mathrm{Ca}^{2+}$ influx and attenuates the release of glutamate (Liu et al., 1996; Imaizumi et al., 1999). Based on these results, an in vivo study using a rat model of spinal cord ischemia confirmed that MVIIC is capable of decreasing glutamate release and $\mathrm{Ca}^{2+}$ influx into the cell (Oliveira et al., 2014). Moreover, MVIIC treatment also preserves neuronal integrity, reduces cell death and hemorrhagic process, and leads to enhanced performance in behavioral tests (Oliveira et al., 2014).

MVIIA, which is an N-type $\mathrm{Ca}^{2+}$ channel blocker, is another $\omega$-conotoxin that has been extensively studied for its neuroprotective properties. Notably, the development of a synthetic version of MVIIA, the SNX-111, facilitated further studies (Olivera et al., 1987). The first studies showed that SNX-111 is effective in preventing neuronal damage after 
transient global ischemia in rat even when administered up to $24 \mathrm{~h}$ after the ischemic insult (Valentino et al., 1993). Using a transient focal ischemia rat model, which was subject to $2 \mathrm{~h}$ MCA occlusion, it was demonstrated that SNX-111 drastically ameliorates brain damage and reduces infarct size (Zhao et al., 1994). Also employing a focal cerebral ischemia rat model, it was shown that SNX-111, administered intravenously at $5 \mathrm{mg} / \mathrm{kg} / \mathrm{h}$ from $20 \mathrm{~min}$ prior to occlusion until $2 \mathrm{~h}$ post occlusion, significantly reduces extracellular glutamate level through inhibition of its presynaptic release. This result was associated with a reduction in the cortical size infarction and neuroprotection (Takizawa et al., 1995). Similar results were observed in a focal cerebral ischemia rabbit model and in a global ischemia rat model (Buchan et al., 1994; Perez-Pinzon et al., 1997). Taking into account all these studies, pharmacokinetic studies were conducted in rats and cynomologus monkeys to determine SNX-111 disposition following $24 \mathrm{~h}$ of continuous, constant-rate intravenous infusion (Bowersox et al., 1997). However, despite all these positive results in vitro and in vivo, when clinical trials were performed to evaluate ZNX-111 effect on ischemia-induced brain injury and chronic pain, positive results were only obtained in the case of chronic pain. Based on these results, the FDA approved the use of SNX-111, which is also known as Ziconotide (Prialt ${ }^{\circledR}$; Elan Pharmaceuticals, Inc.), for the management of severe chronic pain in patients whom intrathecal therapy is authorized, and who are intolerant of or refractory to other treatments (Heading, 2001; McGivern, 2007; Smith and Deer, 2009).

Besides MVIIC and MVIIA, another $\omega$-conopeptide called GVIA, from snail Conus geographus, has also been evaluated for its neuroprotective properties. In vitro experiments showed that GVIA inhibits excessive release of glutamate during ischemia by blocking N-type $\mathrm{Ca}^{2+}$ channel and that this inhibition generates significant protective effect in neurons (Madden et al., 1990; Wang et al., 1992). Regardless of these neuroprotective effects, GVIA has not been extensively studied because its characteristic irreversible binding to the N-type VGCCs limits its clinical potential utility (Wang et al., 1992).

Toxins contained in spider venom have also been shown to inhibit ion channels. For instance, the spider Phoneutria nigriventer venom contains a mixture of toxins that affect ion channels and that have been investigated for the treatment of neurodegenerative processes (Figure 1). The Phoneutria nigriventer venom fraction $\mathrm{PhTx} 3$ contains a broad-spectrum neuronal $\mathrm{Ca}^{2+}$ channel blocker that also inhibits glutamate uptake (Reis et al., 1999). The neuroprotective effects of PhTx3, GVIA and MVIIC were evaluated employing hippocampal slices and mouse cholinergic septal neuronal cell line (SN56 cells), which were subjected to ischemia by oxygen deprivation and low glucose insult. The results from this study indicate that PhTx 3 completely rescues neuronal cell death, although both snail toxins afford only partial cell protection (Pinheiro et al., 2006). After this study, the neuroprotective potential of some of the individual components present in the $\mathrm{PhTx} 3$ fraction were evaluated. The results demonstrated that the PhTx3 components, PhTx3-3 and PhTx3-4, inhibit $\mathrm{Ca}^{2+}$ influx, glutamate release, and exocytosis in nerve endings (Guatimosim et al., 1997; Miranda et al., 1998;
Reis et al., 1999). Next, the in vitro action of PhTx-3-3 and PhTx3-4 on brain injury induced by oxygen deprivation and low glucose insult was investigated using slices of rat hippocampus. In addition to confirm that PhTx-3-3 and PhTx3-4 inhibit the increase of glutamate release, this study showed that these toxins prevent neuronal cell death and rescue the neurotransmission alterations observed in hippocampus CA1 when applied before and after the onset of ischemia (Figure 1) (Pinheiro et al., 2009).

Studies have demonstrated that, apart from excitotoxicity, activation of the $\mathrm{Ca}^{2+}$ permeable ASICs is largely responsible for the development of acidosis-mediated, glutamate-independent ischemic brain injury (Astrup et al., 1977; Xiong et al., 2004). Postsynaptic ASICla is the dominant ASIC subtype in both human and rodent brains and, therefore, its modulation is a potential therapeutic target for ischemia (Li et al., 2010). One of the most potent blockers of ASICla is PcTX, which is obtained from the venom of the South American tarantula, Psalmopoeus cambridgei. Using a rat model of transient focal ischemia, the first studies investigating this venom confirmed the crucial role of ASICla in the pathogenesis of ischemia and the neuroprotective effect of PcTX (Pignataro et al., 2007). It was found that PcTX is able to reduce infarct volume, even if administered after permanent occlusion of the middle cerebral artery, suggesting that ASIC can be activated in the absence of reperfusion. Additionally the intranasal administration of PcTX is nearly as effective as PcTX i.c.v. administration (Xiong et al., 2004; Pignataro et al., 2007). Another study confirmed the beneficial action of PcTX in a newborn piglet model of asphyxia-induced cardiac arrest. Treatment with PcTX reduces striatonigral and striatopallidal neuronal injury, attenuates increased protein kinase A-dependent phosphorylation of DARPP-32 and NMDA receptor NR1 subunit and decreases nitrative and oxidative damage to proteins (Yang Z.J. et al., 2011). The aforementioned studies used whole venom from the spider Psalmopoeus cambridgei. However, it has already been demonstrated that PcTx1, a 40-residue peptide that constitutes a very minor proportion $(\sim 0.4 \%)$ of this venom, is the most selective blocker of ASIC1a (Escoubas et al., 2000a). Moreover, recombinant PcTx1 and PcTxla are equipotent regarding neuroprotection in a conscious hypertensive rat model of transient MCA occlusion (Saez et al., 2011). In addition, animals submitted to conscious stroke that were treated with PcTx1 display intact neuronal architecture, increased number of neurons, and reduced number of caspase-3 positive cells, indicating that this peptide is efficient to prevent apoptosis and foster neuronal survival (McCarthy et al., 2015).

Several other animal toxins have also been shown to be capable of reducing ischemic injury. HWTX-I, an N-type $\mathrm{Ca}^{2+}$ channel blocker, is the most abundant toxic component in the crude venom of the Chinese bird spider Ornithoctonus huwena (Liang et al., 1993). Using a rat model of global cerebral ischemia-reperfusion injury, it was demonstrated that HWTX-I modulates the expression and activity of many apoptosis pathway components, including SOD, glutathione peroxidase, Fas, TNF $\alpha$, caspase-8 and caspase-3 (Wang et al., 2007). Snakes, such as Bothrops atrox and Bothrops brazili, have in their venoms 
serine proteinases capable of promoting angiogenesis through the PI3K/Akt pathway (Bhat et al., 2016). Also by activating the PI3K/Akt pathway, rLj-RGD3, a recombinant toxin from the salivary gland of the Lampetra japonica fish, protects against cerebral ischemia/reperfusion damage (Lu et al., 2016). rLj-RGD3 significantly ameliorates pathological changes in the brain and inhibits neuronal apoptosis by increasing the expression of FAK, p-FAK and Bcl-2 proteins and decreasing the expression of caspase-3 (Lu et al., 2016).

Therefore, many studies have searched for new and effective treatments for ischemia using animal toxins as pharmacological tools (Table 3). Ischemia involves a complex pathogenic cascade of events, which includes energy depletion, excitotoxicity, acidosis, and peri-infarct depolarization, and thus the ideal treatment might need to make use of combined therapies maybe employing two or more toxins.

\section{Glaucoma}

Degeneration of RGCs is a key feature of major ophthalmologic conditions such as glaucoma, diabetic retinopathy and retinal ischemia. The second most common cause of blindness is glaucoma. The disease is characterized by degeneration of RGCs and atrophy of intracranial optic nerves, lateral geniculate nucleus and visual cortex (Gupta et al., 2006). Glaucoma shares several common mechanisms with other neurodegenerative diseases, including oxidative stress, impaired axonal transport, neuroinflammation, excitotoxicity and even deposition of $\mathrm{A} \beta$, $\alpha$-synuclein and phosphorylated tau in the retina (Gauthier and Liu, 2016; Ramirez et al., 2017). Thus, although glaucoma was originally regarded as an eye disease, more recently, it has been suggested that it could be considered a CNS degenerative disease (Weber et al., 2000; Yucel et al., 2003; Gupta et al., 2006). Elevated intra-ocular-pressure is a hallmark of the disease and also the only modifiable factor for therapeutically targeting the pathology (Gauthier and Liu, 2016). The exact mechanisms underlying disease progression are still largely unknown.

Recent studies have demonstrated that spider venom compounds hold potential to treat glaucoma (Table 4). For instance, it has been shown that components of the Brazilian spider Parawixia bistriata venom are neuroprotective. Using a rat glaucoma model based on ischemia/reperfusion of retina, it was shown that the compound called FrPbAII promoted neuroprotection of the retinal cell layers and was also capable of crossing the BBB (Beleboni et al., 2006). Parawixin 1, another compound purified from the venom of Parawixia bistriata, similarly to FrPbAII, has neuroprotective effects demonstrated on retina ischemia/reperfusion glaucoma models (Fachim et al., 2015). Also from Parawixia bistriata venom, PbTx1.2.3, has protected neurons from degeneration in the ischemia/reperfusion retina model, probably through anti excitotoxic activity (Fontana et al., 2003). These results strongly suggest that Parawixia bistriata venom components are potential therapeutic tools.

The venom of Phoneutria nigriventer has also been studied for retina neuroprotection. Excessive influx of $\mathrm{Ca}^{2+}$ through VGCCs triggers the activation of degradative enzymes, increases the levels of ROS and free radicals and promotes oxidative stress in the cell (Siesjo, 1992). It is therefore easy to assume that blockage of VGCCs could hold therapeutic potential. Indeed, PhTx3-3 and PhTx3-4 toxins purified from Phoneutria nigriventer venom, blockers of $\mathrm{N}-\mathrm{P} / \mathrm{Q} \mathrm{Ca}^{2+}$ channels, protect rat retinal slices submitted to the oxygen deprivation and low glucose (ODLG) ischemic insult model (Figure 1) (Agostini et al., 2011). Subsequent research demonstrated that PhTx3-3 has an in vivo neuroprotective effect over rat retinas challenged with NMDA induced injury. Results showed reduced glutamate release as well as reduced levels of ROS, free radicals, oxidative stress and degradative enzymes following pretreatment with PhTx3-3 (Binda et al., 2016). These results suggest a role for Phoneutria nigriventer venom toxins as potential therapeutic agents for managing neurodegenerative retinopathies, encouraging further studies.

\section{Amyotrophic Lateral Sclerosis}

Amyotrophic lateral sclerosis is a neurodegenerative disease characterized by progressive degeneration of upper and lower motoneurons and that is ultimately fatal (Rowland and Shneider, 2001). The sporadic form of the disease accounts for most of the cases $(\sim 90 \%)$, indicating that no obvious genetic component is responsible for triggering the disease. Meanwhile, the remaining $10 \%$ of the cases are attributed to genetic mutations constituting the familial cases of ALS (Greenway et al., 2006; Abhinav et al., 2007). The major symptoms are general muscle spasticity, fasciculation, atrophy and paralysis, leading to death by respiratory failure in 3-5 years from symptoms onset (Walling, 1999). Some studies suggest an association of increased risk to develop ALS and cigarette smoke (Weisskopf et al., 2009), exposure to chemical and metal contaminants (Yu et al., 2014; Roberts et al., 2016), and exposure to radiation and electromagnetic fields (Phillips et al., 1998). Athletes have a higher risk to develop the disease, although there are controversial results regarding physical activity and ALS incidence (Beghi et al., 2010; Huisman et al., 2011). In that regard, several genes previously recognized as ALS risk factors are also related to exercise, which could explain these controversial data (Chen et al., 2004). Riluzole is the only currently available pharmacotherapy to treat ALS patients, extending life expectancy in about 3 months. Although Riluzole mechanism of action is not completely understood, it has been shown that it probably involves inhibition of ionic channels such as $\mathrm{Na}^{+}, \mathrm{K}^{+}$, and $\mathrm{Ca}^{2+}$ channels (Bensimon et al., 1994; Bellingham, 2011).

Within the familial cases of ALS, mutations on the SOD1 gene are the most common (Dangoumau et al., 2014; Zarei et al., 2015). Treatment of symptomatic SOD1 mutant mice (hSOD $1^{\mathrm{G} 93 \mathrm{~A}}$ ) with $\mathrm{BV}$ promotes extended survival, improved motor function, reduced microglial activation and improved mitochondrial integrity (Yang et al., 2010). Further research demonstrated that melittin, isolated from BV, also decreases pathological inflammation, improves motor function and reduces neuronal cell death and $\alpha$-synuclein misfolding (Yang E.J. et al., 2011). Other studies report the efficacy of BV in reducing expression of inflammatory mediators in the lungs, liver, spleen and kidneys of hSOD1 ${ }^{\mathrm{G} 93 \mathrm{~A}}$ mice. Moreover, these effects might be modulated by the selection of specific acupuncture points 
TABLE 3 | Animal toxins to treat brain ischemia.

\begin{tabular}{|c|c|c|c|c|}
\hline Toxin/Substance & Species of origin & Effects & Experimental model & Reference \\
\hline$\omega$-conotoxin MVIIC & Conus magus (snail) & $\begin{array}{l}\text { Neuroprotective } \\
\text { Reduces } \mathrm{Ca}^{2+} \text { influx and glutamate } \\
\text { release } \\
\text { Reduces hemorrhage } \\
\text { Improves performance in behavioral } \\
\text { tests }\end{array}$ & $\begin{array}{l}\text { Spinal cord neuronal cell culture } \\
\text { Spinal cord ischemia rat model }\end{array}$ & $\begin{array}{l}\text { Liu et al., 1996; } \\
\text { Imaizumi et al., 1999; } \\
\text { Oliveira et al., } 2014\end{array}$ \\
\hline$\omega$-conotoxin MVIIA/SNX-111 & Conus magus (snail) & $\begin{array}{l}\text { Neuroprotective } \\
\text { Reduce neuronal damage } \\
\text { Reduce infarct size } \\
\text { Reduce glutamate release }\end{array}$ & $\begin{array}{l}\text { Rat cerebral transient focal } \\
\text { ischemia model } \\
\text { Rabbit cerebral focal ischemia } \\
\text { model } \\
\text { Rat global ischemia model }\end{array}$ & $\begin{array}{l}\text { Valentino et al., 1993; } \\
\text { Zhao et al., 1994; } \\
\text { Takizawa et al., 1995; } \\
\text { Buchan et al., 1994; } \\
\text { Perez-Pinzon et al., } 1997\end{array}$ \\
\hline$\omega$-conotoxin GVIA & $\begin{array}{l}\text { Conus geographus } \\
\text { (snail) }\end{array}$ & $\begin{array}{l}\text { Neuroprotective } \\
\text { Reduces glutamate release }\end{array}$ & $\begin{array}{l}\text { Rat cortical neuronal culture } \\
\text { hypoxia model } \\
\text { Rabbit spinal cord transient } \\
\text { ischemia model }\end{array}$ & $\begin{array}{l}\text { Madden et al., 1990; } \\
\text { Wang et al., } 1992\end{array}$ \\
\hline PhTx3 (T×3-3 and Tx3-4) & $\begin{array}{l}\text { Phoneutria nigriventer } \\
\text { (spider) }\end{array}$ & $\begin{array}{l}\text { Neuroprotective } \\
\text { Reduce } \mathrm{Ca}^{2+} \text { and glutamate } \\
\text { release } \\
\text { Restore normal neurotransmission }\end{array}$ & $\begin{array}{l}\text { Rat hippocampal slices ODLG } \\
\text { model } \\
\text { SN56 cells ODLG model }\end{array}$ & $\begin{array}{l}\text { Pinheiro et al., 2006; } \\
\text { Guatimosim et al., 1997; } \\
\text { Miranda et al., 1998; } \\
\text { Reis et al., } 1999\end{array}$ \\
\hline Psalmotoxin-1 (PcTX) & $\begin{array}{l}\text { Psalmopeous } \\
\text { cambridgei (spider) }\end{array}$ & $\begin{array}{l}\text { Reduces infarct volume, neuronal } \\
\text { damage and oxidative stress } \\
\text { Reduces excessive NMDA NR1 } \\
\text { subunit and DARPP-32 } \\
\text { phosphorylation } \\
\text { Antiapoptotic }\end{array}$ & $\begin{array}{l}\text { Rat cerebral transient focal } \\
\text { ischemia model } \\
\text { Piglet model of asphyxia-induced } \\
\text { cardiac arrest } \\
\text { Hypertensive rat model of transient } \\
\text { MCA occlusion }\end{array}$ & $\begin{array}{l}\text { Escoubas et al., 2000a; } \\
\text { Xiong et al., 2004; } \\
\text { Pignataro et al., 2007; } \\
\text { Saez et al., 2011; } \\
\text { Yang Z.J. et al., 2011; } \\
\text { McCarthy et al., } 2015\end{array}$ \\
\hline Huwentoxin-I (HWTX-I) & $\begin{array}{l}\text { Ornithoctonus huwena } \\
\text { (spider) }\end{array}$ & Antiapoptotic & $\begin{array}{l}\text { Rat global ischemia-reperfusion } \\
\text { model }\end{array}$ & Wang et al., 2007 \\
\hline Serine proteases & $\begin{array}{l}\text { Bothrops asper } \\
\text { and brazili } \\
\text { (snakes) }\end{array}$ & Promote angiogenesis & $\begin{array}{l}\text { Endothelial, Fibroblast and HEK293 } \\
\text { cell culture } \\
\text { Agarose plug transplantation assay }\end{array}$ & Bhat et al., 2016 \\
\hline$r L j-R G$ & Lampetra japonica (fish) & $\begin{array}{l}\text { Neuroprotective } \\
\text { Antiapoptotic }\end{array}$ & $\begin{array}{l}\text { Rat middle cerebral artery occlusion } \\
\text { model }\end{array}$ & Lu et al., 2016 \\
\hline
\end{tabular}

TABLE 4 | Animal toxins to treat glaucoma.

\begin{tabular}{|c|c|c|c|c|}
\hline Toxin/Substance & Species of origin & Effects & Experimental model & Reference \\
\hline $\begin{array}{l}\text { FrPbAll } \\
\text { Parawixin } 1 \\
\text { PbTx1.2.3 }\end{array}$ & $\begin{array}{l}\text { Parawixia bistriata } \\
\text { (spider) }\end{array}$ & Neuroprotective & $\begin{array}{l}\text { Rat retinal cells culture } \\
\text { ischemia/reperfusion model }\end{array}$ & $\begin{array}{l}\text { Fontana et al., 2003; } \\
\text { Beleboni et al., 2006; } \\
\text { Fachim et al., } 2015\end{array}$ \\
\hline $\begin{array}{l}\text { PhTx3-3 } \\
\text { PhTx3-4 }\end{array}$ & $\begin{array}{l}\text { Phoneutria nigriventer } \\
\text { (spider) }\end{array}$ & $\begin{array}{l}\text { Neuroprotective } \\
\text { Reduce ROS, oxidative stress } \\
\text { and degradative enzymes }\end{array}$ & $\begin{array}{l}\text { Rat retinal cells culture } \\
\text { ODLG model } \\
\text { In vivo NMDA intravitreal } \\
\text { administration in rats }\end{array}$ & $\begin{array}{l}\text { Agostini et al., 2011; } \\
\text { Binda et al., } 2016\end{array}$ \\
\hline
\end{tabular}

(Lee et al., 2014, 2015). Another in vitro study used NSC43 motor neuronal cells transfected with either WT or a GFPhSOD ${ }^{\text {G58R }}$ construct to assess BV treatment effects (Kim et al., 2013). GFP-hSOD $1^{\text {G58R }}$ overexpression induced formation of SOD1 inclusions and inhibited proteasome activity. Both effects were reverted by BV treatment, although no autophagic pathway was activated (Kim et al., 2013).

Finally, some studies have demonstrated that the SSM venom has a positive effect on various diseases, including cancer, stroke and epilepsy (Gomes et al., 1983; Cai et al., 2013). However, in most studies, SSM extract and not isolated toxins was tested. SSM extract was also investigated in ALS pathology. Treatment with SSM extract significantly protected hSOD $1{ }^{\text {G93A }}$ mice lumbar spinal cord cells from neurodegeneration (Cai et al., 2013).
Thus, compounds found in BV and SSM venom are potential therapeutic tools to treat ALS (Table 5).

\section{Multiple Sclerosis}

In contrast to the other neurodegenerative diseases, MS is an autoimmune disease, remarkably characterized by pathologic inflammation and increased immunologic activity (Katz Sand, 2015; Pawate and Bagnato, 2015). MS is often described as a $\mathrm{T}$ cell-mediated disease, as a common MS feature is that Th-17 CD4 ${ }^{+}$cells cross the BBB and cause neuronal damage such as axon demyelination and neuronal cell death (Kebir et al., 2007). Th-17 lymphocyte cells secrete interleukin-17, an inflammatory mediator that is inhibited by IFN $\beta$. Indeed, the approval of therapeutic administration of IFN $\beta$ to MS patients in 
TABLE 5 | Animal toxins to treat amyotrophic lateral sclerosis.

\begin{tabular}{|c|c|c|c|c|}
\hline Toxin/Substance & Species of origin & Effects & Experimental model & Reference \\
\hline $\begin{array}{l}\text { Bee venom } \\
\text { Mellitin }\end{array}$ & Apis mellifera (Honey bee) & $\begin{array}{l}\text { Increase survival } \\
\text { Improve motor function } \\
\text { Anti-inflammatory } \\
\text { Neuroprotective } \\
\text { Reduce } \alpha \text {-synuclein misfolding }\end{array}$ & $\begin{array}{l}\text { hSOD1 }{ }^{\text {G93A }} \text { mice } \\
\text { hSOD1 }{ }^{\text {G58R }} \text { mice }\end{array}$ & $\begin{array}{l}\text { Yang et al., 2010; } \\
\text { Yang E.J. et al., 2011; } \\
\text { Kim et al., } 2013\end{array}$ \\
\hline SSM venom extract & $\begin{array}{l}\text { Scolopendra subspinipes } \\
\text { mutilans (centipede) }\end{array}$ & Neuroprotective & hSOD1 ${ }^{\text {G93A }}$ mice & Cai et al., 2013 \\
\hline
\end{tabular}

1993 was a landmark for disease treatment (Paty and Li, 1993). Men are twice as likely to be affected by the disease and the main symptoms are gait problems, visual impairment, fatigue, sexual and bladder dysfunctions (smooth muscle dysfunctions), dementia and others (Halbreich, 1993). MS pathogenesis is complex and can be classified according to disease progression. A recent review has summarized the current classification of the five MS subtypes: Relapse remitting MS, clinically isolated syndrome, radiologic isolated syndrome, primary progressive MS and secondary progressive MS (Lublin, 2014). The majority of MS cases $(\sim 80 \%)$ are relapse remitting, which means that acute periods of disease exacerbation are followed by periods of complete recover and stability.

All MS available treatments are aimed toward reducing relapse frequency and severity, avoid permanent disability and delay or even prevent progression to secondary progressive MS, although so far no curative drug has been developed (Ontaneda et al., 2012; Kamm et al., 2014). Approved drugs are glatiramer acetate, teriflunomide, natalizumab, fingolimod, mitoxantrone, and different isoforms of IFN $\beta$. Corticosteroids have also long been applied for treating the inflammatory and immunomediated character of the disease (Ontaneda et al., 2012; Kamm et al., 2014).

Fortunately, current pharmacotherapy for MS is constantly expanding, even though only modest improvements are achieved through these drugs, which implicates in an ongoing need for novel therapeutic options. Venom based therapy in MS has been explored in several studies showing some positive evidences (Table 6). ShK, a sea anemone (Stichodactyla helianthus) toxin blocker of Kv1.3 channels, which are crucial for activated T lymphocytes action, has shown beneficial effects on autoimmune encephalomyelitis, a MS rat model (Norton et al., 2004). Scorpion venom components have long been described as therapeutic options to treat the disease. Impaired nerve conduction was reversed by scorpion venom treatment (Adam et al., 1966; Bostock et al., 1978). Furthermore, a case report describes that a 43 year old man affected by MS for 3 years was bitten by a scorpion and several improvements in MS symptoms took place until the man was completely asymptomatic for the following 2 months (Breland and Currier, 1983). Kaliotoxin, isolated from scorpion venom, is also a highly selective blocker of Kv1.3 channels. Positive results in the experimental encephalomyelitis model are also available for this toxin blocking lymphocytes $\mathrm{T}$ action (Breland and Currier, 1983; Beeton et al., 2001).

In some MS lesions, penetration of fibrinogen into the brain through damaged parts of the $\mathrm{BBB}$ contributes to the pathological process of the disease. Increased fibrin deposition on lesion sites has been reported in subjects with MS (Adams et al., 2004). Experimental evidences suggest that preventing fibrin deposition enhances nervous system regeneration capability (Akassoglou et al., 2000). Batroxobin, a toxin from the South American viper Bothrops atrox moojeni, reduces circulating levels of fibrinogen through conversion to an insoluble form. Treatment with batroxobin suppressed clinical signs of auto immune encephalomyelitis in rats by preventing fibrin deposition (Inoue et al., 1996; Iwai et al., 1999). Several other snake venoms are also rich in anti-fibrinogen components such as ancrod and crotalase, from the venoms of Calloselasma rhodostoma and Crotalus adamanteus, respectively, providing further research substrates for MS applications (Bell, 1997; Dempfle et al., 2000). Finally, regarding snake derived compounds, CAMNTX, a modified derivative of cobratoxin, induces resistance to experimental allergic encephalomyelitis and reduces lymphocyte brain infiltration on a guinea pig model (Hinman et al., 1999). Altogether, this evidence suggests a possible role for snake venom therapy in MS.

TABLE 6 | Animal toxins to treat multiple sclerosis.

\begin{tabular}{|c|c|c|c|c|}
\hline Toxin/Substance & Species of origin & Effects & Experimental model & Reference \\
\hline Bee Venom & $\begin{array}{l}\text { Apis mellifera } \\
\text { (Honey bee) }\end{array}$ & $\begin{array}{l}\text { Ameliorates disease symptoms } \\
\text { Reduces inflammatory markers }\end{array}$ & $\begin{array}{l}\text { Autoimmune } \\
\text { encephalomyelitis rat }\end{array}$ & Karimi et al., 2012 \\
\hline
\end{tabular}


BV and its components are also under investigation as drug candidates against MS. On the preclinical experimental encephalomyelitis rat model, administration of BV decreased disease symptoms and serum levels of TNF- $\alpha$ and nitrate (Karimi et al., 2012). Clinical evaluations of BV therapy have also been carried out with inconclusive results so far. In 2001, a clinical trial with 51 MS subjects receiving at least weekly shots of BV was completed. Although the study showed some limitations as difficulty to determine whether observed improvements came from BV therapy or periods of disease relapse, and the fact that two different sources of $\mathrm{BV}$ had to be used throughout the experiment, the study was completed with positive outcomes (Hauser et al., 2004). An overall analysis of symptoms improvement showed that $68 \%$ of the subjects declared some kind of positive effect from BV therapy. Most noticeable improvements were reduced fatigue, increased energy levels for everyday activities, improved balance and coordination, muscular strength, and bladder control (Hauser et al., 2004). Later on, in 2005, two other clinical studies investigated BV therapy (Castro et al., 2005; Wesselius et al., 2005). The first study had a total of nine MS subjects enrolled. Although four of the nine cases experienced some worsening of neurological symptoms, the five remaining cases informed some subjective amelioration of disease symptoms. No intense side effects were reported from BV therapy (Castro et al., 2005). The second study was a larger randomized crossover study conducted with 26 MS subjects receiving bee stings three times a week for 24 weeks (Wesselius et al., 2005). Again, BV therapy was well tolerated with no significant adverse side effects. However, the number of new gadolinium-enhancing lesions, an important diagnostic criterion for evaluating MS progression, was unchanged by BV therapy. Furthermore, relapse rate, fatigue, muscular disability and overall life quality were also unchanged after BV treatment (Wesselius et al., 2005). In sum, these data indicate that BV therapy efficacy might be dependent on the protocol used (e.g., number of shots per week), the study subjects (i.e., relapseremitting vs. secondary-progressive cases), and the models used. Although side effects have not been a concern, it cannot be ruled out as limitations for BV therapy until further data from larger studies are collected.

\section{PERSPECTIVES FOR FUTURE USE OF ANIMAL TOXINS}

Venoms are fruitful natural sources of new molecules, which have been relentlessly enhanced by evolution through natural selection. Generally, venom components possess peculiar characteristics such as low-molecular mass, stability, high potency, apart from selectivity and affinity for a wide variety of targets in mammalian systems (Jones and Bulaj, 2000; Casewell et al., 2013). The studies discussed in this review highlight toxins exhibiting potential for either decreasing or even inhibiting the progression of neurodegenerative processes. However, despite all these studies about the application of animal toxins as therapeutic tools to treat neurodegenerative processes, few molecules were tested in clinical trials. In this review, we mentioned BV clinical trials in subjects with PD (Cho et al., 2012; Hartmann et al., 2016) and SNX-111 in subjects with cerebral ischemia (Heading, 2001; Smith and Deer, 2009). The low representativeness of these studies is due to several reasons. First, the scientific evidences showing benefits of a particular toxin in a neurodegenerative disease are not, in most cases, sufficiently strong to justify the studies in humans. Most of the studies described are still preliminary, and often were performed without the correct controls and/or using just one animal model. Among the studies that have compared the effectiveness of a toxin and another drug used as positive control, we could highlight the studies investigating $\mathrm{BV}$ and the dopamine agonist pramipexole in a PD model (Kim et al., 2011); a study that compares BVPLA 2 with donepezil, a FDA-approved drug that inhibit cholinesterase in an AD model (Ye et al., 2016b); as well as studies comparing the performance of Phoneutria nigriventer toxins to Conus toxins in ischemia models (Pinheiro et al., 2006, 2009). Second, the animal models employed to study neurodegenerative diseases possess several limitations, mainly due to our restricted knowledge about disease etiology (Dauer and Przedborski, 2003; Jucker, 2010). Most neurodegenerative diseases are a consequence of sporadic factors or the sum of neuropathological events, making it difficult to develop an animal model that recapitulates all the complex clinical features of human diseases. For instance, most animal models are generated through genetic mutation, recapitulating familial neurodegenerative diseases, which only represent a small fraction of the cases. Thus, without employing reliable animal models, it is difficult to select and test toxins to be used in clinical trials. The third reason for this lack of success is that many of the studies described here used crude venom without evaluating the compounds in isolation, which restricts the knowledge about the neuroprotective mechanisms and hinder studies aiming to enhance compound pharmacological properties. In most cases, the methodological approach to separate the different compounds present in venom can be daunting. In addition, we have to consider the difficulty to obtain biologically active fractions. Research involving animal venoms is not a trivial task and there are many bioanalytical challenges to overcome, as well as the intrinsically time-consuming process of elucidation the occurrence of synergistic actions between components present in the poison (Bliss, 1939). The fourth reason is that the amount of venom obtained from animals is insufficient to perform all the necessary experiments and tests. As mentioned previously, venoms are extremely potent and, thus, small amounts are sufficient for animals' need, such as defending themselves from predators or attacking prey. Although most research with animal toxins uses native proteins that are obtained directly from animals, an alternative approach would be synthesis either by recombinant expression or chemical production (Zhao et al., 1994; Perez-Pinzon et al., 1997; Lu et al., 2016; Smith et al., 2016).

Recombinant proteins are produced by employing the recombinant DNA technique, whereby the DNA sequence encoding the protein of interest is inserted into a plasmid and subsequently introduced into a host organism, such as bacteria or yeast, which will be induced to express the gene of interest. This method enables the production of proteins 
that are the same or similar to the original, facilitating the acquisition of large quantities and/or with superior activity (Cohen et al., 1973; Harris et al., 1986; Kopetzki et al., 1989). However, production of recombinant proteins is not an easy assignment and depends on the proper selection of suitable hosts and vectors. Besides, there is no guarantee to obtain a structurally active protein at the end of the process. Toxins are molecules that possess many cysteine and disulfide bridges that are important for protein proper folding, which makes their production even more difficult with aggregation often limiting the yield of properly folded proteins (Fahnert, 2012). These problems occur because, in most cases, the primary host of choice for the production of recombinant proteins is bacteria, mainly Escherichia coli. Undoubtedly, the production of recombinant proteins in prokaryote systems has revolutionized biochemistry. Bacterial protein expression systems are popular because they are easy to culture, fast growing and yield large quantities of recombinant protein. However, if eukaryotic post-translational modifications (like disulfide bridges) are indispensable for protein folding and activity, a prokaryotic expression system may not be convenient (Rosano and Ceccarelli, 2014; Stefan et al., 2015). In that case, mammalian or insect cells may be a more suitable system for recombinant protein production. These systems are able to facilitate protein proper folding and enable post-translational modifications, which are important for full biological activity. Despite these advantages, these expression systems are not widely used due to their high cost, complicated technology, and potential for contamination with proteins from mammalian cell viruses (Khan, 2013). Chemical synthesis of proteins, especially using established solid-phase techniques is a fast and effective technique, and can be employed to overcome some of the disadvantages of current protein production methods using cell systems (Marglin and Merrifield, 1970; Borgia and Fields, 2000; Kent, 2003). However, this methodology also has its limitations, such as aggregation of growing peptide chains, numerous secondary reactions and low yields of long peptides (>25-30 residues) (Nilsson et al., 2005).

Despite all the limitations of the studies performed and the difficulties in obtaining toxins, either from the native source or by artificial methods, their neuroprotective abilities are undeniable. Moreover, many drugs approved during the past decades are based on animal's toxins or their compounds. Some successful examples are Prialt ${ }^{\circledR}$ (ziconotide), which is a synthetic version

\section{REFERENCES}

Abhinav, K., Stanton, B., Johnston, C., Hardstaff, J., Orrell, R. W., Howard, R., et al. (2007). Amyotrophic lateral sclerosis in South-East England: a populationbased study. The South-East England register for amyotrophic lateral sclerosis (SEALS Registry). Neuroepidemiology 29, 44-48. doi: 10.1159/0001 08917

Abramov, A. Y., Scorziello, A., and Duchen, M. R. (2007). Three distinct mechanisms generate oxygen free radicals in neurons and contribute to cell death during anoxia and reoxygenation. J. Neurosci. 27, 1129-1138. doi: 10.1523/JNEUROSCI.4468-06.2007

Adam, K. R., Schmidt, H., Stampfli, R., and Weiss, C. (1966). The effect of scorpion venom on single myelinated nerve fibres of the frog. Br. J. Pharmacol. Chemother. 26, 666-677. doi: 10.1111/j.1476-5381.1966.tb01846.x of $\omega$-conotoxin MVIIA found in the venom of the fish-eating marine snail, Conus magus, and used to treat severe chronic pain (Heading, 2001; McGivern, 2007); angiotensin I-converting enzyme inhibitors, derived from the venom of the South American Lancehead snake (Bothrops jararaca), which was the lead compound used for the development of anti-hypertensive drugs such as Captopril ${ }^{\circledR}$ and its analogs (Rocha et al., 1949; Ferreira et al., 1970; Cushman and Ondetti, 1980); the inhibitor of platelet aggregation drug Aggrastat ${ }^{\circledR}$ (tirobifan), derived from the venom of the saw scaled viper Echis carinatus (Garsky et al., 1989); Integrilin ${ }^{\circledR}$ (Eptifibatide), an anticoagulant drug derived from the venom of the southeastern pygmy rattlesnake (Sistrurus miliarius barbouri) (Platelet Glycoprotein IIb/IIIa in Unstable Angina: Receptor Suppression Using Integrilin Therapy (PURSUIT) Trial Investigators, 1998; Hashemzadeh et al., 2008); and Byetta ${ }^{\circledR}$ (exenatide) derived from the venom of the Gila monster (Heloderma suspectum) and used as treatment for diabetes type II (Nielsen et al., 2004; Triplitt and Chiquette, 2006). Therefore, it is possible that in the near future animal toxins might offer new and effective therapeutic options, facilitating the development of disease-modifying drugs to treat neurodegenerative diseases.

\section{AUTHOR CONTRIBUTIONS}

JdS and BG helped design the study and wrote the manuscript. FR and LV drafted the study and substantially contributed to the conception of the work. FR, LV, and MG revised this study critically for important intellectual content. All authors approved the final version of the manuscript.

\section{FUNDING}

This work was supported by FINEP and FAPEMIG grants to FR and CNPq and FAPEMIG grants to LV.

\section{ACKNOWLEDGMENTS}

Authors thank Isabella G. Olmo for her insightful comments and suggestions regarding figure design.

Adams, R. A., Passino, M., Sachs, B. D., Nuriel, T., and Akassoglou, K. (2004). Fibrin mechanisms and functions in nervous system pathology. Mol. Interv. 4, 163-176.

Agostini, R. M., do Nascimento Pinheiro, A. C., Binda, N. S., Romano Silva, M. A., do Nascimento, Cordeiro, M., et al. (2011). Phoneutria spider toxins block ischemia-induced glutamate release and neuronal death of cell layers of the retina. Retina 31, 1392-1399. doi: 10.1097/IAE.0b013e31820 5 b249

Akassoglou, K., Kombrinck, K. W., Degen, J. L., and Strickland, S. (2000). Tissue plasminogen activator-mediated fibrinolysis protects against axonal degeneration and demyelination after sciatic nerve injury. J. Cell Biol. 149, 1157-1166. doi: $10.1083 /$ jcb.149.5.1157

Alvarez-Fischer, D., Noelker, C., Vulinovic, F., Grunewald, A., Chevarin, C., Klein, C., et al. (2013). Bee venom and its component apamin as neuroprotective 
agents in a Parkinson disease mouse model. PLoS One 8:e61700. doi: 10.1371/ journal.pone.0061700

Alzheimer, A. (1907). Über eine eigenartige erkrankung der hirnrinde. Allg. Z. Psychiat. Psychisch Gerichtl. Med. 64, 146-148.

Anderson, D. W., Neavin, T., Smith, J. A., and Schneider, J. S. (2001). Neuroprotective effects of pramipexole in young and aged MPTP-treated mice. Brain Res. 905, 44-53. doi: 10.1016/S0006-8993(01)02466-0

Anderton, B. H., Brion, J. P., Flament-Durand, J., Haugh, M. C., Kahn, J., Miller, C. C., et al. (1987). Neurofibrillary tangles and the neuronal cytoskeleton. J. Neural Transm. Suppl. 24, 191-196.

Anfinsen, C. B. (1973). Principles that govern the folding of protein chains. Science 181, 223-230. doi: 10.1126/science.181.4096.223

Anstey, K. J., von Sanden, C., Salim, A., and O’Kearney, R. (2007). Smoking as a risk factor for dementia and cognitive decline: a meta-analysis of prospective studies. Am. J. Epidemiol. 166, 367-378. doi: 10.1093/aje/kwm116

Armstrong, R. A. (2014). Factors determining disease duration in Alzheimer's disease: a postmortem study of 103 cases using the Kaplan-Meier estimator and Cox regression. Biomed Res. Int. 2014:623487. doi: 10.1155/2014/623487

Arundine, M., and Tymianski, M. (2004). Molecular mechanisms of glutamatedependent neurodegeneration in ischemia and traumatic brain injury. Cell Mol. Life Sci. 61, 657-668. doi: 10.1007/s00018-003-3319-x

Astrup, J., Symon, L., Branston, N. M., and Lassen, N. A. (1977). Cortical evoked potential and extracellular $\mathrm{K}+$ and $\mathrm{H}+$ at critical levels of brain ischemia. Stroke 8, 51-57. doi: 10.1161/01.STR.8.1.51

Awad, K., Abushouk, A. I., AbdelKarim, A. H., Mohammed, M., Negida, A., and Shalash, A. S. (2017). Bee venom for the treatment of Parkinson's disease: How far is it possible? Biomed. Pharmacother. 91, 295-302. doi: 10.1016/j.biopha. 2017.04.065

Ayoub, S., and Melzig, M. F. (2006). Induction of neutral endopeptidase (NEP) activity of SK-N-SH cells by natural compounds from green tea. J. Pharm. Pharmacol. 58, 495-501. doi: 10.1211/jpp.58.4.0009

Azarias, G., Perreten, H., Lengacher, S., Poburko, D., Demaurex, N., Magistretti, P. J., et al. (2011). Glutamate transport decreases mitochondrial $\mathrm{pH}$ and modulates oxidative metabolism in astrocytes. J. Neurosci. 31, 3550-3559. doi: 10.1523/JNEUROSCI.4378-10.2011

Balhara, K. S., and Stolbach, A. (2014). Marine envenomations. Emerg. Med. Clin. North Am. 32, 223-243. doi: 10.1016/j.emc.2013.09.009

Beal, M. F., Ferrante, R. J., Browne, S. E., Matthews, R. T., Kowall, N. W., Brown, R. H. Jr., et al. (1997). Increased 3-nitrotyrosine in both sporadic and familial amyotrophic lateral sclerosis. Ann. Neurol. 42, 644-654. doi: 10.1002/ ana. 410420416

Beeton, C., Barbaria, J., Giraud, P., Devaux, J., Benoliel, A. M., Gola, M., et al. (2001). Selective blocking of voltage-gated $\mathrm{K}+$ channels improves experimental autoimmune encephalomyelitis and inhibits T cell activation. J. Immunol. 166, 936-944. doi: 10.4049/jimmunol.166.2.936

Beghi, E., Logroscino, G., Chio, A., Hardiman, O., Millul, A., Mitchell, D., et al. (2010). Amyotrophic lateral sclerosis, physical exercise, trauma and sports: results of a population-based pilot case-control study. Amyotroph. Lateral Scler. 11, 289-292. doi: 10.3109/17482960903384283

Beitz, J. M. (2014). Parkinson's disease: a review. Front. Biosci. 6, 65-74. doi: $10.2741 / \mathrm{S} 415$

Beleboni, R. O., Guizzo, R., Fontana, A. C., Pizzo, A. B., Carolino, R. O., GobboNeto, L., et al. (2006). Neurochemical characterization of a neuroprotective compound from Parawixia bistriata spider venom that inhibits synaptosomal uptake of GABA and glycine. Mol. Pharmacol. 69, 1998-2006. doi: 10.1124/mol. 105.017319

Bell, W. R. Jr. (1997). Defibrinogenating enzymes. Drugs 54(Suppl. 3), 18-30; discussion 30-31. doi: 10.2165/00003495-199700543-00005

Bellingham, M. C. (2011). A review of the neural mechanisms of action and clinical efficiency of riluzole in treating amyotrophic lateral sclerosis: what have we learned in the last decade? CNS Neurosci. Ther. 17, 4-31. doi: 10.1111/j.17555949.2009.00116.x

Bennett, J. P. Jr., and Piercey, M. F. (1999). Pramipexole-a new dopamine agonist for the treatment of Parkinson's disease. J. Neurol. Sci. 163, 25-31. doi: 10.1016/ S0022-510X(98)00307-4

Bensimon, G., Lacomblez, L., and Meininger, V. (1994). A controlled trial of riluzole in amyotrophic lateral sclerosis. ALS/Riluzole Study Group. N. Engl. J. Med. 330, 585-591. doi: 10.1056/NEJM199403033300901
Berke, S. J., and Paulson, H. L. (2003). Protein aggregation and the ubiquitin proteasome pathway: gaining the UPPer hand on neurodegeneration. Curr. Opin. Genet. Dev. 13, 253-261. doi: 10.1016/S0959-437X(03)00053-4

Bhat, S. K., Joshi, M. B., Ullah, A., Masood, R., Biligiri, S. G., Arni, R. K., et al. (2016). Serine proteinases from Bothrops snake venom activates PI3K/Akt mediated angiogenesis. Toxicon 124, 63-72. doi: 10.1016/j.toxicon.2016. 11.001

Bhattacharjee, P., and Bhattacharyya, D. (2013). Factor V activator from Daboia russelli russelli venom destabilizes beta-amyloid aggregate, the hallmark of Alzheimer disease. J. Biol. Chem. 288, 30559-30570. doi: 10.1074/jbc.M113. 511410

Biardi, J. E., and Coss, R. G. (2011). Rock squirrel (Spermophilus variegatus) blood sera affects proteolytic and hemolytic activities of rattlesnake venoms. Toxicon 57, 323-331. doi: 10.1016/j.toxicon.2010.12.011

Biessels, G. J., Staekenborg, S., Brunner, E., Brayne, C., and Scheltens, P. (2006). Risk of dementia in diabetes mellitus: a systematic review. Lancet Neurol. 5, 64-74. doi: 10.1016/S1474-4422(05)70284-2

Binda, N. S., Carayon, C. P., Agostini, R. M., Pinheiro, A. C., Cordeiro, M. N., Silva, M. A., et al. (2016). PhTx3-4, a spider toxin calcium channel blocker, reduces NMDA-induced injury of the retina. Toxins 8:E70. doi: 10.3390/toxins803 0070

Bliss, C. I. (1939). The toxicity of poisons applied jointly. Ann. Appl. Biol. 26, 585-615. doi: 10.1111/j.1744-7348.1939.tb06990.x

Bolisetty, S., and Jaimes, E. A. (2013). Mitochondria and reactive oxygen species: physiology and pathophysiology. Int. J. Mol. Sci. 14, 6306-6344. doi: 10.3390/ ijms14036306

Booth, L. A., Tavallai, S., Hamed, H. A., Cruickshanks, N., and Dent, P. (2014). The role of cell signalling in the crosstalk between autophagy and apoptosis. Cell. Signal. 26, 549-555. doi: 10.1016/j.cellsig.2013.11.028

Borgia, J. A., and Fields, G. B. (2000). Chemical synthesis of proteins. Trends Biotechnol. 18, 243-251. doi: 10.1016/S0167-7799(00)01445-1

Bostock, H., Sherratt, R. M., and Sears, T. A. (1978). Overcoming conduction failure in demyelinated nerve fibres by prolonging action potentials. Nature 274, 385-387. doi: 10.1038/274385a0

Bowersox, S., Mandema, J., Tarczy-Hornoch, K., Miljanich, G., and Luther, R. R. (1997). Pharmacokinetics of SNX-111, a selective N-type calcium channel blocker, in rats and cynomolgus monkeys. Drug Metab. Dispos. 25, 379-383.

Bowersox, S. S., Gadbois, T., Singh, T., Pettus, M., Wang, Y. X., and Luther, R. R. (1996). Selective N-type neuronal voltage-sensitive calcium channel blocker, SNX-111, produces spinal antinociception in rat models of acute, persistent and neuropathic pain. J. Pharmacol. Exp. Ther. 279, 1243-1249.

Breland, A. E., and Currier, R. D. (1983). Scorpion venom and multiple sclerosis. Lancet 2:1021. doi: 10.1016/S0140-6736(83)90996-0

Brunk, U. T., and Terman, A. (2002). The mitochondrial-lysosomal axis theory of aging: accumulation of damaged mitochondria as a result of imperfect autophagocytosis. Eur. J. Biochem. 269, 1996-2002. doi: 10.1046/j.1432-1033. 2002.02869.x

Brunner, H. R., Gavras, H., Waeber, B., Textor, S. C., Turini, G. A., and Wauters, J. P. (1980). Clinical use of an orally acting converting enzyme inhibitor: captopril. Hypertension 2, 558-566. doi: 10.1161/01.HYP.2.4.558

Buchan, A. M., Gertler, S. Z., Li, H., Xue, D., Huang, Z. G., Chaundy, K. E., et al. (1994). A selective N-type $\mathrm{Ca}^{2+}$-channel blocker prevents CA1 injury 24 $\mathrm{h}$ following severe forebrain ischemia and reduces infarction following focal ischemia. J. Cereb. Blood Flow Metab. 14, 903-910. doi: 10.1038/jcbfm.1994.121

Butterfield, D. A., Castegna, A., Lauderback, C. M., and Drake, J. (2002). Evidence that amyloid beta-peptide-induced lipid peroxidation and its sequelae in Alzheimer's disease brain contribute to neuronal death. Neurobiol. Aging 23, 655-664. doi: 10.1016/S0197-4580(01)00340-2

Cai, M., Choi, S. M., Song, B. K., Son, I., Kim, S., and Yang, E. J. (2013). Scolopendra subspinipes mutilans attenuates neuroinflammation in symptomatic hSOD1(G93A) mice. J. Neuroinflammation 10:131. doi: 10.1186/ 1742-2094-10-131

Cai, M., Lee, J. H., and Yang, E. J. (2016). Bee venom ameliorates cognitive dysfunction caused by neuroinflammation in an animal model of vascular dementia. Mol. Neurobiol. 54, 5952-5960. doi: 10.1007/s12035-016-0130-x

Calmette, A. (1894). L'immunisation artificielle des animaux contre le venin des serpents, et la thérapeutique expérimentale des morsures venimeuses. C. R. Soc. Biol. 46, 120-124. 
Casewell, N. R., Wuster, W., Vonk, F. J., Harrison, R. A., and Fry, B. G. (2013). Complex cocktails: the evolutionary novelty of venoms. Trends Ecol. Evol. 28, 219-229. doi: 10.1016/j.tree.2012.10.020

Castellani, R. J., Rolston, R. K., and Smith, M. A. (2010). Alzheimer disease. Dis. Mon. 56, 484-546. doi: 10.1016/j.disamonth.2010.06.001

Castrioto, A., Piscicelli, C., Perennou, D., Krack, P., and Debu, B. (2014). The pathogenesis of Pisa syndrome in Parkinson's disease. Mov. Disord. 29, 1100-1107. doi: 10.1002/mds. 25925

Castro, H. J., Mendez-Lnocencio, J. I., Omidvar, B., Omidvar, J., Santilli, J., Nielsen, H. S. Jr., et al. (2005). A phase I study of the safety of honeybee venom extract as a possible treatment for patients with progressive forms of multiple sclerosis. Allergy Asthma Proc. 26, 470-476.

Changeux, J. P., Kasai, M., and Lee, C. Y. (1970). Use of a snake venom toxin to characterize the cholinergic receptor protein. Proc. Natl. Acad. Sci. U.S.A. 67, 1241-1247. doi: 10.1073/pnas.67.3.1241

Chen, Y. Z., Bennett, C. L., Huynh, H. M., Blair, I. P., Puls, I., Irobi, J., et al. (2004). DNA/RNA helicase gene mutations in a form of juvenile amyotrophic lateral sclerosis (ALS4). Am. J. Hum. Genet. 74, 1128-1135. doi: 10.1086/421054

Cho, S. Y., Shim, S. R., Rhee, H. Y., Park, H. J., Jung, W. S., Moon, S. K., et al. (2012). Effectiveness of acupuncture and bee venom acupuncture in idiopathic Parkinson's disease. Parkinsonism Relat. Disord. 18, 948-952. doi: 10.1016/j. parkreldis.2012.04.030

Choi, D. S., Wang, D., Yu, G. Q., Zhu, G., Kharazia, V. N., Paredes, J. P., et al. (2006). PKCepsilon increases endothelin converting enzyme activity and reduces amyloid plaque pathology in transgenic mice. Proc. Natl. Acad. Sci. U.S.A. 103, 8215-8220. doi: 10.1073/pnas.0509725103

Choi, D. W. (1994). Calcium and excitotoxic neuronal injury. Ann. N. Y. Acad. Sci. 747, 162-171. doi: 10.1111/j.1749-6632.1994.tb44407.x

Choi, D. W. (1995). Calcium: still center-stage in hypoxic-ischemic neuronal death. Trends Neurosci. 18, 58-60. doi: 10.1016/0166-2236(95)80018-W

Chung, E. S., Kim, H., Lee, G., Park, S., Kim, H., and Bae, H. (2012). Neuroprotective effects of bee venom by suppression of neuroinflammatory responses in a mouse model of Parkinson's disease: role of regulatory T cells. Brain Behav. Immun. 26, 1322-1330. doi: 10.1016/j.bbi.2012.08.013

Chung, E. S., Lee, G., Lee, C., Ye, M., Chung, H. S., Kim, H., et al. (2015). Bee venom phospholipase A2, a novel Foxp3+ regulatory $\mathrm{T}$ cell inducer, protects dopaminergic neurons by modulating neuroinflammatory responses in a mouse model of Parkinson's disease. J. Immunol. 195, 4853-4860. doi: 10.4049/jimmunol.1500386

Cicchetti, F., Brownell, A. L., Williams, K., Chen, Y. I., Livni, E., and Isacson, O. (2002). Neuroinflammation of the nigrostriatal pathway during progressive 6OHDA dopamine degeneration in rats monitored by immunohistochemistry and PET imaging. Eur. J. Neurosci. 15, 991-998. doi: 10.1046/j.1460-9568.2002. 01938.x

Clarfield, A. M. (2003). The decreasing prevalence of reversible dementias: an updated meta-analysis. Arch. Intern. Med. 163, 2219-2229. doi: 10.1001/ archinte.163.18.2219

Cohen, S. N., Chang, A. C., Boyer, H. W., and Helling, R. B. (1973). Construction of biologically functional bacterial plasmids in vitro. Proc. Natl. Acad. Sci. U.S.A. 70, 3240-3244. doi: 10.1073/pnas.70.11.3240

Coyle, J. T., Price, D. L., and DeLong, M. R. (1983). Alzheimer's disease: a disorder of cortical cholinergic innervation. Science 219, 1184-1190. doi: $10.1126 /$ science.6338589

Cushman, D. W., and Ondetti, M. A. (1980). Inhibitors of angiotensin-converting enzyme. Prog. Med. Chem. 17, 41-104. doi: 10.1016/S0079-6468(08)70157-7

da Silva, R. J., da Silva, M. G., Vilela, L. C., and Fecchio, D. (2002). Antitumor effect of Bothrops jararaca venom. Mediators Inflamm. 11, 99-104. doi: 10.1080/ 09629350220131953

Dangoumau, A., Verschueren, A., Hammouche, E., Papon, M. A., Blasco, H., Cherpi-Antar, C., et al. (2014). Novel SOD1 mutation p.V31A identified with a slowly progressive form of amyotrophic lateral sclerosis. Neurobiol. Aging 35, 266.e1-266.e4. doi: 10.1016/j.neurobiolaging.2013.07.012

Darwin, C. R. (1859). On the Origin of Species. London: John Murray.

Dasuri, K., Zhang, L., and Keller, J. N. (2013). Oxidative stress, neurodegeneration, and the balance of protein degradation and protein synthesis. Free Radic. Biol. Med. 62, 170-185. doi: 10.1016/j.freeradbiomed.2012.09.016

Dauer, W., and Przedborski, S. (2003). Parkinson's disease: mechanisms and models. Neuron 39, 889-909. doi: 10.1016/S0896-6273(03)00568-3
David, S., and Kroner, A. (2011). Repertoire of microglial and macrophage responses after spinal cord injury. Nat. Rev. Neurosci. 12, 388-399. doi: 10.1038/ nrn3053

Davies, S. W., Turmaine, M., Cozens, B. A., DiFiglia, M., Sharp, A. H., Ross, C. A., et al. (1997). Formation of neuronal intranuclear inclusions underlies the neurological dysfunction in mice transgenic for the HD mutation. Cell 90, 537-548. doi: 10.1016/S0092-8674(00)80513-9

Dempfle, C. E., Argiriou, S., Kucher, K., Muller-Peltzer, H., Rubsamen, K., and Heene, D. L. (2000). Analysis of fibrin formation and proteolysis during intravenous administration of ancrod. Blood 96, 2793-2802.

Deng, Y. T., Huang, H. C., and Lin, J. K. (2010). Rotenone induces apoptosis in MCF-7 human breast cancer cell-mediated ROS through JNK and p38 signaling. Mol. Carcinog. 49, 141-151. doi: 10.1002/mc.20583

De-Paula, V. J., Radanovic, M., Diniz, B. S., and Forlenza, O. V. (2012). Alzheimer's disease. Subcell. Biochem. 65, 329-352. doi: 10.1007/978-94-007-5416-4_14

Dias, V., Junn, E., and Mouradian, M. M. (2013). The role of oxidative stress in Parkinson's disease. J. Parkinsons Dis. 3, 461-491. doi: 10.3233/JPD- 130230

DiFiglia, M., Sapp, E., Chase, K. O., Davies, S. W., Bates, G. P., Vonsattel, J. P., et al. (1997). Aggregation of huntingtin in neuronal intranuclear inclusions and dystrophic neurites in brain. Science 277, 1990-1993. doi: 10.1126/science.277. 5334.1990

Doo, A. R., Kim, S. T., Kim, S. N., Moon, W., Yin, C. S., Chae, Y., et al. (2010). Neuroprotective effects of bee venom pharmaceutical acupuncture in acute 1-methyl-4-phenyl-1,2,3,6-tetrahydropyridine-induced mouse model of Parkinson's disease. Neurol. Res. 32(Suppl. 1), 88-91. doi: 10.1179/ 016164109X12537002794282

Duyckaerts, C., Delatour, B., and Potier, M. C. (2009). Classification and basic pathology of Alzheimer disease. Acta Neuropathol. 118, 5-36. doi: 10.1007/ s00401-009-0532-1

El-Amouri, S. S., Zhu, H., Yu, J., Marr, R., Verma, I. M., and Kindy, M. S. (2008). Neprilysin: an enzyme candidate to slow the progression of Alzheimer's disease. Am. J. Pathol. 172, 1342-1354. doi: 10.2353/ajpath.2008.070620

Elmore, S. (2007). Apoptosis: a review of programmed cell death. Toxicol. Pathol. 35, 495-516. doi: 10.1080/01926230701320337

Elobeid, A., Libard, S., Leino, M., Popova, S. N., and Alafuzoff, I. (2016). Altered proteins in the aging brain. J. Neuropathol. Exp. Neurol. 75, 316-325. doi: 10.1093/jnen/nlw002

Escoubas, P., and Bosmans, F. (2007). Spider peptide toxins as leads for drug development. Expert Opin. Drug Discov. 2, 823-835. doi: 10.1517/17460441.2. 6.823

Escoubas, P., De Weille, J. R., Lecoq, A., Diochot, S., Waldmann, R., Champigny, G., et al. (2000a). Isolation of a tarantula toxin specific for a class of proton-gated $\mathrm{Na}^{+}$channels. J. Biol. Chem. 275, 25116-25121.

Escoubas, P., Diochot, S., and Corzo, G. (2000b). Structure and pharmacology of spider venom neurotoxins. Biochimie 82, 893-907.

Ezzo, J., Hadhazy, V., Birch, S., Lao, L., Kaplan, G., Hochberg, M., et al. (2001). Acupuncture for osteoarthritis of the knee: a systematic review. Arthritis Rheum. 44, 819-825. doi: 10.1002/1529-0131(200104)44:4<819::AIDANR138>3.0.CO;2-P

Fachim, H. A., Mortari, M. R., Gobbo-Netto, L., and Dos Santos, W. F. (2015). Neuroprotective activity of parawixin 10, a compound isolated from Parawixia bistriata spider venom (Araneidae: Araneae) in rats undergoing intrahippocampal NMDA microinjection. Pharmacogn. Mag. 11, 579-585. doi: 10.4103/0973-1296.160450

Fahnert, B. (2012). Using folding promoting agents in recombinant protein production: a review. Methods Mol. Biol. 824, 3-36. doi: 10.1007/978-1-61779433-9_1

Fenard, D., Lambeau, G., Maurin, T., Lefebvre, J. C., and Doglio, A. (2001). A peptide derived from bee venom-secreted phospholipase A2 inhibits replication of T-cell tropic HIV-1 strains via interaction with the CXCR4 chemokine receptor. Mol. Pharmacol. 60, 341-347. doi: 10.1124/mol.60. 2.341

Ferreira, S. H., Bartelt, D. C., and Greene, L. J. (1970). Isolation of bradykininpotentiating peptides from Bothrops jararaca venom. Biochemistry 9, 2583-2593. doi: 10.1021/bi00815a005

Ferri, C. P., Prince, M., Brayne, C., Brodaty, H., Fratiglioni, L., Ganguli, M., et al. (2005). Global prevalence of dementia: a Delphi consensus study. Lancet 366, 2112-2117. doi: 10.1016/S0140-6736(05)67889-0 
Fontana, A. C., Guizzo, R., de Oliveira Beleboni, R., Meirelles Silva, A. R., Meirelles E Silva, A. R., Coimbra, N. C., et al. (2003). Purification of a neuroprotective component of Parawixia bistriata spider venom that enhances glutamate uptake. Br. J. Pharmacol. 139, 1297-1309. doi: 10.1038/sj.bjp.0705352

Friedrich, R. P., Tepper, K., Ronicke, R., Soom, M., Westermann, M., Reymann, K., et al. (2010). Mechanism of amyloid plaque formation suggests an intracellular basis of Abeta pathogenicity. Proc. Natl. Acad. Sci. U.S.A. 107, 1942-1947. doi: 10.1073/pnas.0904532106

Fry, B. G., Roelants, K., Champagne, D. E., Scheib, H., Tyndall, J. D., King, G. F., et al. (2009). The toxicogenomic multiverse: convergent recruitment of proteins into animal venoms. Annu. Rev. Genomics Hum. Genet. 10, 483-511. doi: 10.1146/annurev.genom.9.081307.164356

Gandhi, S., and Abramov, A. Y. (2012). Mechanism of oxidative stress in neurodegeneration. Oxid. Med. Cell. Longev. 2012:428010. doi: 10.1155/2012/ 428010

Garin, D., Virgone-Carlotta, A., Gozel, B., Oukhatar, F., Perret, P., Marti-Battle, D., et al. (2015). COB231 targets amyloid plaques in post-mortem human brain tissue and in an Alzheimer mouse model. J. Neurochem. 132, 609-618. doi: $10.1111 /$ jnc. 12951

Garland, J. M., and Halestrap, A. (1997). Energy metabolism during apoptosis. $\mathrm{Bcl}-2$ promotes survival in hematopoietic cells induced to apoptose by growth factor withdrawal by stabilizing a form of metabolic arrest. J. Biol. Chem. 272, 4680-4688. doi: 10.1074/jbc.272.8.4680

Garsky, V. M., Lumma, P. K., Freidinger, R. M., Pitzenberger, S. M., Randall, W. C., Veber, D. F., et al. (1989). Chemical synthesis of echistatin, a potent inhibitor of platelet aggregation from Echis carinatus: synthesis and biological activity of selected analogs. Proc. Natl. Acad. Sci. U.S.A. 86, 4022-4026. doi: 10.1073/pnas.86.11.4022

Garthwaite, G., and Garthwaite, J. (1986). Neurotoxicity of excitatory amino acid receptor agonists in rat cerebellar slices: dependence on calcium concentration. Neurosci. Lett. 66, 193-198. doi: 10.1016/0304-3940(86)90189-8

Gauthier, A. C., and Liu, J. (2016). Neurodegeneration and neuroprotection in glaucoma. Yale J. Biol. Med. 89, 73-79.

Gautier, E. L., Shay, T., Miller, J., Greter, M., Jakubzick, C., Ivanov, S., et al. (2012). Gene-expression profiles and transcriptional regulatory pathways that underlie the identity and diversity of mouse tissue macrophages. Nat. Immunol. 13, 1118-1128. doi: 10.1038/ni.2419

Gazewood, J. D., Richards, D. R., and Clebak, K. (2013). Parkinson disease: an update. Am. Fam. Phys. 87, 267-273.

George, J. L., Mok, S., Moses, D., Wilkins, S., Bush, A. I., Cherny, R. A., et al. (2009). Targeting the progression of Parkinson's disease. Curr. Neuropharmacol. 7, 9-36. doi: 10.2174/157015909787602814

Ghosh, A., Roy, A., Liu, X., Kordower, J. H., Mufson, E. J., Hartley, D. M., et al. (2007). Selective inhibition of NF-kappaB activation prevents dopaminergic neuronal loss in a mouse model of Parkinson's disease. Proc. Natl. Acad. Sci. U.S.A. 104, 18754-18759. doi: 10.1073/pnas.0704908104

Giasson, B. I., Duda, J. E., Murray, I. V., Chen, Q., Souza, J. M., Hurtig, H. I., et al. (2000a). Oxidative damage linked to neurodegeneration by selective alpha-synuclein nitration in synucleinopathy lesions. Science 290, 985-989.

Giasson, B. I., Jakes, R., Goedert, M., Duda, J. E., Leight, S., Trojanowski, J. Q., et al. (2000b). A panel of epitope-specific antibodies detects protein domains distributed throughout human alpha-synuclein in Lewy bodies of Parkinson's disease. J. Neurosci. Res. 59, 528-533.

Glenner, G. G., and Wong, C. W. (1984). Alzheimer's disease: initial report of the purification and characterization of a novel cerebrovascular amyloid protein. Biochem. Biophys. Res. Commun. 120, 885-890. doi: 10.1016/S0006-291X(84) 80190-4

Goate, A., Chartier-Harlin, M.-C., Mullan, M., Brown, J., Crawford, F., Fidani, L., et al. (1991). Segregation of a missense mutation in the amyloid precursor protein gene with familial Alzheimer's disease. Nature 349, 704-706. doi: $10.1038 / 349704 \mathrm{a} 0$

Goedert, M., and Spillantini, M. G. (2006). A century of Alzheimer's disease. Science 314, 777-781. doi: 10.1126/science.1132814

Gomes, A., Datta, A., Sarangi, B., Kar, P. K., and Lahiri, S. C. (1983). Isolation, purification \& pharmacodynamics of a toxin from the venom of the centipede Scolopendra subspinipes dehaani Brandt. Indian J. Exp. Biol. 21, 203-207.

Gomes, G. M., Dalmolin, G. D., Cordeiro Mdo, N., Gomez, M. V., Ferreira, J., and Rubin, M. A. (2013). The selective A-type $\mathrm{K}^{+}$current blocker Tx3-1 isolated from the Phoneutria nigriventer venom enhances memory of naive and Abeta(25-35)-treated mice. Toxicon 76, 23-27. doi: 10.1016/j.toxicon.2013. 08.059

Greenway, M. J., Andersen, P. M., Russ, C., Ennis, S., Cashman, S., Donaghy, C., et al. (2006). ANG mutations segregate with familial and 'sporadic' amyotrophic lateral sclerosis. Nat. Genet. 38, 411-413. doi: 10.1038/ng 1742

Griffiths, H. R. (2005). ROS as signalling molecules in T cells-evidence for abnormal redox signalling in the autoimmune disease, rheumatoid arthritis. Redox Rep. 10, 273-280. doi: 10.1179/135100005X83680

Gu, S. M., Park, M. H., Hwang, C. J., Song, H. S., Lee, U. S., Han, S. B., et al. (2015). Bee venom ameliorates lipopolysaccharide-induced memory loss by preventing NF-kappaB pathway. J. Neuroinflammation 12:124. doi: 10.1186/s12974-0150344-2

Guatimosim, C., Romano-Silva, M. A., Cruz, J. S., Beirao, P. S., Kalapothakis, E., Moraes-Santos, T., et al. (1997). A toxin from the spider Phoneutria nigriventer that blocks calcium channels coupled to exocytosis. Br. J. Pharmacol. 122, 591-597. doi: 10.1038/sj.bjp.0701381

Guerreiro, R. J., Gustafson, D. R., and Hardy, J. (2012). The genetic architecture of Alzheimer's disease: beyond APP, PSENs and APOE. Neurobiol. Aging 33, 437-456. doi: 10.1016/j.neurobiolaging.2010.03.025

Guerriero, R. M., Giza, C. C., and Rotenberg, A. (2015). Glutamate and GABA imbalance following traumatic brain injury. Curr. Neurol. Neurosci. Rep. 15:27. doi: 10.1007/s11910-015-0545-1

Gupta, N., Ang, L. C., Noel de Tilly, L., Bidaisee, L., and Yucel, Y. H. (2006). Human glaucoma and neural degeneration in intracranial optic nerve, lateral geniculate nucleus, and visual cortex. Br. J. Ophthalmol. 90, 674-678. doi: 10.1136/bjo. 2005.086769

Halbreich, U. (1993). Multiple Sclerosis: A Neuropsychiatric Disorder. Washington, DC: American Psychiatric Press.

Harel, M., Kleywegt, G. J., Ravelli, R. B., Silman, I., and Sussman, J. L. (1995). Crystal structure of an acetylcholinesterase-fasciculin complex: interaction of a three-fingered toxin from snake venom with its target. Structure 3, 1355-1366. doi: 10.1016/S0969-2126(01)00273-8

Harris, T. J., Patel, T., Marston, F. A., Little, S., Emtage, J. S., Opdenakker, G., et al. (1986). Cloning of cDNA coding for human tissue-type plasminogen activator and its expression in Escherichia coli. Mol. Biol. Med. 3, 279-292.

Hartmann, A., Mullner, J., Meier, N., Hesekamp, H., van Meerbeeck, P., Habert, M. O., et al. (2016). Bee venom for the treatment of Parkinson disease a randomized controlled clinical trial. PLoS One 11:e0158235. doi: 10.1371/ journal.pone.0158235

Hashemzadeh, M., Furukawa, M., Goldsberry, S., and Movahed, M. R. (2008). Chemical structures and mode of action of intravenous glycoprotein IIb/IIIa receptor blockers: a review. Exp. Clin. Cardiol. 13, 192-197.

Hauser, R. A., Daguio, M., Wester, D., Hauser, M., Kirchman, A., and Skinkis, C. (2004). Bee-venom therapy for treating multiple sclerosis: a clinical trial. Altern. Complement. Ther. 7, 37-45. doi: 10.1089/107628001300000714

Heading, C. E. (2001). Ziconotide (elan pharmaceuticals). IDrugs 4, 339-350.

Herczenik, E., and Gebbink, M. F. (2008). Molecular and cellular aspects of protein misfolding and disease. FASEB J. 22, 2115-2133. doi: 10.1096/fj.07-099671

Hernandez, D. G., Nalls, M. A., Gibbs, J. R., Arepalli, S., van der Brug, M., Chong, S., et al. (2011). Distinct DNA methylation changes highly correlated with chronological age in the human brain. Hum. Mol. Genet. 20, 1164-1172. doi: $10.1093 / \mathrm{hmg} / \mathrm{ddq} 561$

Herskind, A. M., McGue, M., Holm, N. V., Sorensen, T. I., Harvald, B., and Vaupel, J. W. (1996). The heritability of human longevity: a population-based study of 2872 Danish twin pairs born 1870-1900. Hum. Genet. 97, 319-323. doi: 10.1007/BF02185763

Hillyard, D. R., Monje, V. D., Mintz, I. M., Bean, B. P., Nadasdi, L., Ramachandran, J., et al. (1992). A new conus peptide ligand for mammalian presynaptic $\mathrm{Ca}^{2+}$ channels. Neuron 9, 69-77. doi: 10.1016/0896-6273(92) 90221-X

Hinman, C. L., Stevens-Truss, R., Schwarz, C., and Hudson, R. A. (1999). Sequence determinants of modified cobra venom neurotoxin which induce immune resistance to experimental allergic encephalomyelitis: molecular mechanisms for immunologic action. Immunopharmacol. Immunotoxicol. 21, 483-506. doi: $10.3109 / 08923979909007122$ 
Hirsch, E. C., and Hunot, S. (2009). Neuroinflammation in Parkinson's disease: a target for neuroprotection? Lancet Neurol. 8, 382-397. doi: 10.1016/S14744422(09)70062-6

Holtzman, D. M., Morris, J. C., and Goate, A. M. (2011). Alzheimer's disease: the challenge of the second century. Sci. Transl. Med. 3:77sr1. doi: 10.1126/ scitranslmed.3002369

Horiguchi, T., Uryu, K., Giasson, B. I., Ischiropoulos, H., LightFoot, R., Bellmann, C., et al. (2003). Nitration of tau protein is linked to neurodegeneration in tauopathies. Am. J. Pathol. 163, 1021-1031. doi: 10.1016/ S0002-9440(10)63462-1

Hroudova, J., Singh, N., and Fisar, Z. (2014). Mitochondrial dysfunctions in neurodegenerative diseases: relevance to Alzheimer's disease. Biomed Res. Int. 2014:175062. doi: 10.1155/2014/175062

Huisman, M. H., de Jong, S. W., van Doormaal, P. T., Weinreich, S. S., Schelhaas, H. J., van der Kooi, A. J., et al. (2011). Population based epidemiology of amyotrophic lateral sclerosis using capture-recapture methodology. J. Neurol. Neurosurg. Psychiatry 82, 1165-1170. doi: 10.1136/jnnp.2011. 244939

Hynd, M. R., Scott, H. L., and Dodd, P. R. (2004). Glutamate-mediated excitotoxicity and neurodegeneration in Alzheimer's disease. Neurochem. Int. 45, 583-595. doi: 10.1016/j.neuint.2004.03.007

Imaizumi, T., Kocsis, J. D., and Waxman, S. G. (1999). The role of voltage-gated $\mathrm{Ca}^{2+}$ channels in anoxic injury of spinal cord white matter. Brain Res. 817, 84-92. doi: 10.1016/S0006-8993(98)01214-1

Inoue, A., Koh, C. S., Shimada, K., Yanagisawa, N., and Yoshimura, K. (1996). Suppression of cell-transferred experimental autoimmune encephalomyelitis in defibrinated Lewis rats. J. Neuroimmunol. 71, 131-137. doi: 10.1016/S01655728(96)00150-6

Iwai, S., Okazaki, M., Kiuchi, Y., and Oguchi, K. (1999). Changes in mRNA levels of fibrinogen subunit polypeptides in rats defibrinogenated with batroxobin. Thromb. Res. 96, 421-426. doi: 10.1016/S0049-3848(99)00135-8

Jansa, S. A., and Voss, R. S. (2011). Adaptive evolution of the venom-targeted vWF protein in opossums that eat pitvipers. PLoS One 6:e20997. doi: 10.1371/journal. pone.0020997

Johnson, D. K., Storandt, M., Morris, J. C., Langford, Z. D., and Galvin, J. E. (2008). Cognitive profiles in dementia: Alzheimer disease vs healthy brain aging. Neurology 71, 1783-1789. doi: 10.1212/01.wnl.0000335972.35970.70

Johnson, S. C., Dong, X., Vijg, J., and Suh, Y. (2015). Genetic evidence for common pathways in human age-related diseases. Aging Cell 14, 809-817. doi: 10.1111/ acel.12362

Jones, R. M., and Bulaj, G. (2000). Conotoxins - new vistas for peptide therapeutics. Curr. Pharm. Des. 6, 1249-1285. doi: 10.2174/1381612003399653

Jucker, M. (2010). The benefits and limitations of animal models for translational research in neurodegenerative diseases. Nat. Med. 16, 1210-1214. doi: 10.1038/ nm.2224

Kalogeris, T., Baines, C. P., Krenz, M., and Korthuis, R. J. (2012). Cell biology of ischemia/reperfusion injury. Int. Rev. Cell Mol. Biol. 298, 229-317. doi: 10.1016/ B978-0-12-394309-5.00006-7

Kamm, C. P., Uitdehaag, B. M., and Polman, C. H. (2014). Multiple sclerosis: current knowledge and future outlook. Eur. Neurol. 72, 132-141. doi: 10.1159/ 000360528

Kanno, S., Tomizawa, A., Ohtake, T., Koiwai, K., Ujibe, M., and Ishikawa, M. (2006). Naringenin-induced apoptosis via activation of NF-kappaB and necrosis involving the loss of ATP in human promyeloleukemia HL-60 cells. Toxicol. Lett. 166, 131-139. doi: 10.1016/j.toxlet.2006.06.005

Karimi, A., Ahmadi, F., Parivar, K., Nabiuni, M., Haghighi, S., Imani, S., et al. (2012). Effect of honey bee venom on lewis rats with experimental allergic encephalomyelitis, a model for multiple sclerosis. Iran. J. Pharm. Res. 11, 671-678.

Kasturiratne, A., Wickremasinghe, A. R., de Silva, N., Gunawardena, N. K., Pathmeswaran, A., Premaratna, R., et al. (2008). The global burden of snakebite: a literature analysis and modelling based on regional estimates of envenoming and deaths. PLoS Med. 5:e218. doi: 10.1371/journal.pmed.0050218

Katz Sand, I. (2015). Classification, diagnosis, and differential diagnosis of multiple sclerosis. Curr. Opin. Neurol. 28, 193-205. doi: 10.1097/WCO. 0000000000000206

Kebir, H., Kreymborg, K., Ifergan, I., Dodelet-Devillers, A., Cayrol, R., Bernard, M., et al. (2007). Human TH17 lymphocytes promote blood-brain barrier disruption and central nervous system inflammation. Nat. Med. 13, 1173-1175. doi: $10.1038 / \mathrm{nm} 1651$

Kent, S. (2003). Total chemical synthesis of enzymes. J. Pept. Sci. 9, 574-593. doi: $10.1002 /$ psc.475

Kerr, J. F., Wyllie, A. H., and Currie, A. R. (1972). Apoptosis: a basic biological phenomenon with wide-ranging implications in tissue kinetics. Br. J. Cancer 26, 239-257. doi: 10.1038/bjc.1972.33

Khalil, W. K., Assaf, N., ElShebiney, S. A., and Salem, N. A. (2015). Neuroprotective effects of bee venom acupuncture therapy against rotenone-induced oxidative stress and apoptosis. Neurochem. Int. 80, 79-86. doi: 10.1016/j.neuint.2014. 11.008

Khan, K. H. (2013). Gene expression in Mammalian cells and its applications. $A d v$. Pharm. Bull. 3, 257-263. doi: 10.5681/apb.2013.042

Kidd, M. (1963). Paired helical filaments in electron microscopy of Alzheimer's disease. Nature 197, 192-193. doi: 10.1038/197192b0

Kigerl, K. A., Gensel, J. C., Ankeny, D. P., Alexander, J. K., Donnelly, D. J., and Popovich, P. G. (2009). Identification of two distinct macrophage subsets with divergent effects causing either neurotoxicity or regeneration in the injured mouse spinal cord. J. Neurosci. 29, 13435-13444. doi: 10.1523/JNEUROSCI. 3257-09.2009

Kim, H. J., and Jeon, B. S. (2014). Is acupuncture efficacious therapy in Parkinson's disease? J. Neurol. Sci. 341, 1-7. doi: 10.1016/j.jns.2014.04.016

Kim, J. I., Yang, E. J., Lee, M. S., Kim, Y. S., Huh, Y., Cho, I. H., et al. (2011). Bee venom reduces neuroinflammation in the MPTP-induced model of Parkinson's disease. Int. J. Neurosci. 121, 209-217. doi: 10.3109/00207454.2010.548613

Kim, K. S., Cho, H. S., Lee, S. D., Kim, K. H., Cho, J. Y., Chung, K. H., et al. (2005). Inhibitory effect of Buthus martensi Karsch extracts on interleukinlbeta-induced expression of nitric oxide (NO) synthase and production of NO in human chondrocytes and LPS-induced NO and prostaglandin E2 production in mouse peritoneal macrophages. Toxicol. In Vitro 19, 757-769. doi: 10.1016/j. tiv.2005.04.008

Kim, M. E., Lee, J. Y., Lee, K. M., Park, H. R., Lee, E., Lee, Y., et al. (2016). Neuroprotective effect of bee venom is mediated by reduced astrocyte activation in a subchronic MPTP-induced model of Parkinson's disease. Arch. Pharm. Res. 39, 1160-1170. doi: 10.1007/s12272-016-0802-0

Kim, S. H., Jung, S. Y., Lee, K. W., Lee, S. H., Cai, M., Choi, S. M., et al. (2013). Bee venom effects on ubiquitin proteasome system in hSOD1(G85R)expressing NSC34 motor neuron cells. BMC Complement. Altern. Med. 13:179. doi: $10.1186 / 1472-6882-13-179$

Kirik, D., Rosenblad, C., and Bjorklund, A. (1998). Characterization of behavioral and neurodegenerative changes following partial lesions of the nigrostriatal dopamine system induced by intrastriatal 6-hydroxydopamine in the rat. Exp. Neurol. 152, 259-277. doi: 10.1006/exnr.1998.6848

Kirstein-Miles, J., and Morimoto, R. I. (2010). Caenorhabditis elegans as a model system to study intercompartmental proteostasis: interrelation of mitochondrial function, longevity, and neurodegenerative diseases. Dev. Dyn. 239, 1529-1538. doi: 10.1002/dvdy.22292

Klein, C., Patte-Mensah, C., Taleb, O., Bourguignon, J. J., Schmitt, M., Bihel, F., et al. (2013). The neuroprotector kynurenic acid increases neuronal cell survival through neprilysin induction. Neuropharmacology 70, 254-260. doi: 10.1016/j. neuropharm.2013.02.006

Koh, D. C., Armugam, A., and Jeyaseelan, K. (2006). Snake venom components and their applications in biomedicine. Cell Mol. Life Sci. 63, 3030-3041. doi: 10.1007/s00018-006-6315-0

Kopetzki, E., Schumacher, G., and Buckel, P. (1989). Control of formation of active soluble or inactive insoluble baker's yeast alpha-glucosidase PI in Escherichia coli by induction and growth conditions. Mol. Gen. Genet. 216, 149-155. doi: $10.1007 / \mathrm{BF} 00332244$

Kristian, T. (2004). Metabolic stages, mitochondria and calcium in hypoxic/ischemic brain damage. Cell Calcium 36, 221-233. doi: 10.1016/j.ceca. 2004.02.016

Kroemer, G., Galluzzi, L., Vandenabeele, P., Abrams, J., Alnemri, E. S., Baehrecke, E. H., et al. (2009). Classification of cell death: recommendations of the nomenclature committee on cell death 2009. Cell Death Differ. 16, 3-11. doi: $10.1038 /$ cdd. 2008.150

Kumar, K. R., Lohmann, K., and Klein, C. (2012). Genetics of Parkinson disease and other movement disorders. Curr. Opin. Neurol. 25, 466-474. doi: 10.1097/ WCO.0b013e3283547627 
Lang, A. E., and Lozano, A. M. (1998). Parkinson's disease. First of two parts. N. Engl. J. Med. 339, 1044-1053. doi: 10.1056/NEJM199810083391506

Lao, L., Hamilton, G. R., Fu, J., and Berman, B. M. (2003). Is acupuncture safe? A systematic review of case reports. Altern. Ther. Health Med. 9, 72-83.

Lardenoije, R., Iatrou, A., Kenis, G., Kompotis, K., Steinbusch, H. W., Mastroeni, D., et al. (2015). The epigenetics of aging and neurodegeneration. Prog. Neurobiol. 131, 21-64. doi: 10.1016/j.pneurobio.2015.05.002

Lee, E. B. (2011). Obesity, leptin, and Alzheimer's disease. Ann. N. Y. Acad. Sci. 1243, 15-29. doi: 10.1111/j.1749-6632.2011.06274.x

Lee, G., and Bae, H. (2016). Bee venom phospholipase A2: yesterday's enemy becomes today's friend. Toxins 8:48. doi: 10.3390/toxins8020048

Lee, M. S., Pittler, M. H., Shin, B. C., Kong, J. C., and Ernst, E. (2008). Bee venom acupuncture for musculoskeletal pain: a review. J. Pain 9, 289-297. doi: $10.1016 /$ j.jpain.2007.11.012

Lee, S. H., Choi, S. M., and Yang, E. J. (2014). Melittin ameliorates the inflammation of organs in an amyotrophic lateral sclerosis animal model. Exp. Neurobiol. 23, 86-92. doi: $10.5607 /$ en.2014.23.1.86

Lee, S. H., Choi, S. M., and Yang, E. J. (2015). Bee venom acupuncture augments anti-inflammation in the peripheral organs of hSOD1G93A transgenic mice. Toxins 7, 2835-2844. doi: 10.3390/toxins7082835

Levine, B., and Kroemer, G. (2008). Autophagy in the pathogenesis of disease. Cell 132, 27-42. doi: 10.1016/j.cell.2007.12.018

Levy-Lahad, E., Wasco, W., Poorkaj, P., Romano, D. M., Oshima, J., Pettingell, W. H., et al. (1995). Candidate gene for the chromosome 1 familial Alzheimer's disease locus. Science 269, 973-977. doi: 10.1126/science.7638622

Li, M., Inoue, K., Branigan, D., Kratzer, E., Hansen, J. C., Chen, J. W., et al. (2010). Acid-sensing ion channels in acidosis-induced injury of human brain neurons. J. Cereb. Blood Flow Metab. 30, 1247-1260. doi: 10.1038/jcbfm.2010.30

Liang, S. P., Zhang, D. Y., Pan, X., Chen, Q., and Zhou, P. A. (1993). Properties and amino acid sequence of huwentoxin-I, a neurotoxin purified from the venom of the Chinese bird spider Selenocosmia huwena. Toxicon 31, 969-978. doi: 10.1016/0041-0101(93)90256-I

Lin, C. L., Winardi, W., Jeng, A. Y., and Kwan, A. L. (2006). Endothelin-converting enzyme inhibitors for the treatment of subarachnoid hemorrhage-induced vasospasm. Neurol. Res. 28, 721-729. doi: 10.1179/016164106X152007

Lipton, P. (1999). Ischemic cell death in brain neurons. Physiol. Rev. 79, 1431-1568. doi: 10.1152/physrev.1999.79.4.1431

Liu, H., De Waard, M., Scott, V. E., Gurnett, C. A., Lennon, V. A., and Campbell, K. P. (1996). Identification of three subunits of the high affinity omegaconotoxin MVIIC-sensitive $\mathrm{Ca}^{2+}$ channel. J. Biol. Chem. 271, 13804-13810. doi: 10.1074/jbc.271.23.13804

Loeffler, D. A., DeMaggio, A. J., Juneau, P. L., Havaich, M. K., and LeWitt, P. A. (1994). Effects of enhanced striatal dopamine turnover in vivo on glutathione oxidation. Clin. Neuropharmacol. 17, 370-379. doi: 10.1097/ 00002826-199408000-00009

Lu, Q., Wang, J., Jiang, J., Wang, S., Jia, Q., Wang, Y., et al. (2016). rLj-RGD3, a novel recombinant toxin protein from Lampetra japonica, protects against cerebral reperfusion injury following middle cerebral artery occlusion involving the integrin-PI3K/Akt pathway in rats. PLoS One 11:e0165093. doi: 10.1371/ journal.pone.0165093

Lublin, F. D. (2014). New multiple sclerosis phenotypic classification. Eur. Neurol. 72(Suppl. 1), 1-5. doi: 10.1159/000367614

Macdonald, M. E., Ambrose, C., Duyao, M. P., and Harper, P. S. (1993). A novel gene containing a trinucleotide repeat that is expanded and unstable on Huntington's disease chromosomes. The Huntington's disease collaborative research group. Cell 72, 971-983. doi: 10.1016/0092-8674(93) 90585-E

Madden, K. P., Clark, W. M., Marcoux, F. W., Probert, A. W. Jr., Weber, M. L., Rivier, J., et al. (1990). Treatment with conotoxin, an 'N-type' calcium channel blocker, in neuronal hypoxic-ischemic injury. Brain Res. 537, 256-262. doi: 10.1016/0006-8993(90)90366-J

Marcaida, G., Minana, M. D., Grisolia, S., and Felipo, V. (1995). Lack of correlation between glutamate-induced depletion of ATP and neuronal death in primary cultures of cerebellum. Brain Res. 695, 146-150. doi: 10.1016/0006-8993(95) 00703-S

Marglin, A., and Merrifield, R. B. (1970). Chemical synthesis of peptides and proteins. Annu. Rev. Biochem. 39, 841-866. doi: 10.1146/annurev.bi.39.070170. 004205
Marsden, C. D. (1990). Parkinson's disease. Lancet 335, 948-952. doi: 10.1016/ 0140-6736(90)91006-V

Martins, N. M., Santos, N. A., Sartim, M. A., Cintra, A. C., Sampaio, S. V., and Santos, A. C. (2015). A tripeptide isolated from Bothrops atrox venom has neuroprotective and neurotrophic effects on a cellular model of Parkinson's disease. Chem. Biol. Interact. 235, 10-16. doi: 10.1016/j.cbi.2015.04.004

Matysiak, J., Schmelzer, C. E., Neubert, R. H., and Kokot, Z. J. (2011). Characterization of honeybee venom by MALDI-TOF and nanoESI-QqTOF mass spectrometry. J. Pharm. Biomed. Anal. 54, 273-278. doi: 10.1016/j.jpba. 2010.08.020

Maurice, N., Deltheil, T., Melon, C., Degos, B., Mourre, C., Amalric, M., et al. (2015). Bee venom alleviates motor deficits and modulates the transfer of cortical information through the basal ganglia in rat models of Parkinson's disease. PLoS One 10:e0142838. doi: 10.1371/journal.pone.0142838

McCarthy, C. A., Rash, L. D., Chassagnon, I. R., King, G. F., and Widdop, R. E. (2015). PcTxl affords neuroprotection in a conscious model of stroke in hypertensive rats via selective inhibition of ASIC1a. Neuropharmacology 99, 650-657. doi: 10.1016/j.neuropharm.2015.08.040

McEnery, M. W., Snowman, A. M., and Snyder, S. H. (1991). Evidence for subtypes of the omega-conotoxin GVIA receptor. Identification of the properties intrinsic to the high-affinity receptor. Ann. N. Y. Acad. Sci. 635, 435-437. doi: 10.1111/j.1749-6632.1991.tb36519.x

McGeer, P. L., Itagaki, S., Boyes, B. E., and McGeer, E. G. (1988). Reactive microglia are positive for HLA-DR in the substantia nigra of Parkinson's and Alzheimer's disease brains. Neurology 38, 1285-1291. doi: 10.1212/WNL.38.8.1285

McGeer, P. L., and McGeer, E. G. (2008). Glial reactions in Parkinson's disease. Mov. Disord. 23, 474-483. doi: $10.1002 / \mathrm{mds} .21751$

McGeer, P. L., Schwab, C., Parent, A., and Doudet, D. (2003). Presence of reactive microglia in monkey substantia nigra years after 1-methyl-4-phenyl-1,2,3,6tetrahydropyridine administration. Ann. Neurol. 54, 599-604. doi: 10.1002/ana. 10728

McGivern, J. G. (2007). Ziconotide: a review of its pharmacology and use in the treatment of pain. Neuropsychiatr. Dis. Treat. 3, 69-85. doi: 10.2147/nedt.2007. 3.1.69

Mebs, D. (1989). Snake venoms: toolbox of the neurobiologist. Endeavour 13, 157-161. doi: 10.1016/S0160-9327(89)80003-1

Meredith, G. E., and Rademacher, D. J. (2011). MPTP mouse models of Parkinson's disease: an update. J. Parkinsons Dis. 1, 19-33. doi: 10.3233/JPD-2011-11023

Mhyre, T. R., Boyd, J. T., Hamill, R. W., and Maguire-Zeiss, K. A. (2012). Parkinson's disease. Subcell. Biochem. 65, 389-455. doi: 10.1007/978-94-0075416-4_16

Mierau, J., and Schingnitz, G. (1992). Biochemical and pharmacological studies on pramipexole, a potent and selective dopamine D2 receptor agonist. Eur. J. Pharmacol. 215, 161-170. doi: 10.1016/0014-2999(92)90024-X

Miller, J. C., Brown, B. D., Shay, T., Gautier, E. L., Jojic, V., Cohain, A., et al. (2012). Deciphering the transcriptional network of the dendritic cell lineage. Nat. Immunol. 13, 888-899. doi: 10.1038/ni.2370

Miranda, D. M., Romano-Silva, M. A., Kalapothakis, E., Diniz, C. R., Cordeiro, M. N., Santos, T. M., et al. (1998). Phoneutria nigriventer toxins block tityustoxin-induced calcium influx in synaptosomes. Neuroreport 9, 1371-1373. doi: 10.1097/00001756-199805110-00022

Mirshafiey, A. (2007). Venom therapy in multiple sclerosis. Neuropharmacology 53 , 353-361. doi: 10.1016/j.neuropharm.2007.05.002

Miyamoto, S., Howes, A. L., Adams, J. W., Dorn, G. W. II, and Brown, J. H. (2005). $\mathrm{Ca}^{2+}$ dysregulation induces mitochondrial depolarization and apoptosis: role of $\mathrm{Na}^{+} / \mathrm{Ca}^{2+}$ exchanger and AKT. J. Biol. Chem. 280, 38505-38512. doi: 10.1074/ jbc.M505223200

Miyasaki, J. M., Martin, W., Suchowersky, O., Weiner, W. J., and Lang, A. E. (2002). Practice parameter: initiation of treatment for Parkinson's disease: an evidencebased review: report of the quality standards subcommittee of the American academy of neurology. Neurology 58, 11-17. doi: 10.1212/WNL.58.1.11

Moreira, P. I., Santos, M. S., and Oliveira, C. R. (2007). Alzheimer's disease: a lesson from mitochondrial dysfunction. Antioxid. Redox Signal. 9, 1621-1630. doi: 10.1089 /ars.2007.1703

Mukherjee, P., Mulrooney, T. J., Marsh, J., Blair, D., Chiles, T. C., and Seyfried, T. N. (2008). Differential effects of energy stress on AMPK phosphorylation and apoptosis in experimental brain tumor and normal brain. Mol. Cancer 7:37. doi: 10.1186/1476-4598-7-37 
Nakanishi, S., and Masu, M. (1994). Molecular diversity and functions of glutamate receptors. Annu. Rev. Biophys. Biomol. Struct. 23, 319-348. doi: 10.1146/ annurev.bb.23.060194.001535

Nakashima, S., Kitamoto, K., and Arioka, M. (2004). The catalytic activity, but not receptor binding, of sPLA2s plays a critical role for neurite outgrowth induction in PC12 cells. Brain Res. 1015, 207-211. doi: 10.1016/j.brainres.2004.04.069

Nalivaeva, N. N., Beckett, C., Belyaev, N. D., and Turner, A. J. (2012). Are amyloid-degrading enzymes viable therapeutic targets in Alzheimer's disease? J. Neurochem. 120(Suppl. 1), 167-185. doi: 10.1111/j.1471-4159.2011.07510.x

Narahashi, T., Moore, J. W., and Frazier, D. T. (1969). Dependence of tetrodotoxin blockage of nerve membrane conductance on external pH. J. Pharmacol. Exp. Ther. 169, 224-228.

Nicholls, D. G., Budd, S. L., Castilho, R. F., and Ward, M. W. (1999). Glutamate excitotoxicity and neuronal energy metabolism. Ann. N. Y. Acad. Sci. 893, 1-12. doi: 10.1111/j.1749-6632.1999.tb07813.x

Nielsen, L. L., Young, A. A., and Parkes, D. G. (2004). Pharmacology of exenatide (synthetic exendin-4): a potential therapeutic for improved glycemic control of type 2 diabetes. Regul. Pept. 117, 77-88. doi: 10.1016/j.regpep.2003.10.028

Nilsson, B. L., Soellner, M. B., and Raines, R. T. (2005). Chemical synthesis of proteins. Annu. Rev. Biophys. Biomol. Struct. 34, 91-118. doi: 10.1146/annurev. biophys.34.040204.144700

Nisani, Z., Boskovic, D. S., Dunbar, S. G., Kelln, W., and Hayes, W. K. (2012). Investigating the chemical profile of regenerated scorpion (Parabuthus transvaalicus) venom in relation to metabolic cost and toxicity. Toxicon 60 , 315-323. doi: 10.1016/j.toxicon.2012.04.343

Nisani, Z., Dunbar, S. G., and Hayes, W. K. (2007). Cost of venom regeneration in Parabuthus transvaalicus (Arachnida: Buthidae). Comp. Biochem. Physiol. A Mol. Integr. Physiol. 147, 509-513. doi: 10.1016/j.cbpa.2007.01.027

Norton, R. S., Pennington, M. W., and Wulff, H. (2004). Potassium channel blockade by the sea anemone toxin ShK for the treatment of multiple sclerosis and other autoimmune diseases. Curr. Med. Chem. 11, 3041-3052. doi: 10.2174/ 0929867043363947

Oliveira, K. M., Lavor, M. S., Silva, C. M., Fukushima, F. B., Rosado, I. R., Silva, J. F., et al. (2014). Omega-conotoxin MVIIC attenuates neuronal apoptosis in vitro and improves significant recovery after spinal cord injury in vivo in rats. Int. J. Clin. Exp. Pathol. 7, 3524-3536.

Olivera, B. M., Cruz, L. J., de Santos, V., LeCheminant, G. W., Griffin, D., Zeikus, R., et al. (1987). Neuronal calcium channel antagonists. Discrimination between calcium channel subtypes using omega-conotoxin from Conus magus venom. Biochemistry 26, 2086-2090. doi: 10.1021/bi00382a004

Ontaneda, D., Hyland, M., and Cohen, J. A. (2012). Multiple sclerosis: new insights in pathogenesis and novel therapeutics. Annu. Rev. Med. 63, 389-404. doi: 10.1146/annurev-med-042910-135833

Ordy, J. M., Wengenack, T. M., Bialobok, P., Coleman, P. D., Rodier, P., Baggs, R. B., et al. (1993). Selective vulnerability and early progression of hippocampal CA1 pyramidal cell degeneration and GFAP-positive astrocyte reactivity in the rat four-vessel occlusion model of transient global ischemia. Exp. Neurol. 119, 128-139. doi: 10.1006/exnr.1993.1014

Orihuela, R., McPherson, C. A., and Harry, G. J. (2016). Microglial M1/M2 polarization and metabolic states. Br. J. Pharmacol. 173, 649-665. doi: 10.1111/ bph.13139

Patten, D. A., Germain, M., Kelly, M. A., and Slack, R. S. (2010). Reactive oxygen species: stuck in the middle of neurodegeneration. J. Alzheimers Dis. 20(Suppl. 2), S357-S367. doi: 10.3233/JAD-2010-100498

Paty, D. W., and Li, D. K. (1993). Interferon beta-1b is effective in relapsingremitting multiple sclerosis. II. MRI analysis results of a multicenter, randomized, double-blind, placebo-controlled trial. UBC MS/MRI study group and the IFNB multiple sclerosis study group. Neurology 43, 662-667. doi: 10.1212/WNL.43.4.662

Pawate, S., and Bagnato, F. (2015). Newer agents in the treatment of multiple sclerosis. Neurologist 19, 104-117. doi: 10.1097/NRL.0000000000000020

Pedersen, W. A., Fu, W., Keller, J. N., Markesbery, W. R., Appel, S., Smith, R. G., et al. (1998). Protein modification by the lipid peroxidation product 4hydroxynonenal in the spinal cords of amyotrophic lateral sclerosis patients. Ann. Neurol. 44, 819-824. doi: 10.1002/ana.410440518

Pepe, S. (2000). Mitochondrial function in ischaemia and reperfusion of the ageing heart. Clin. Exp. Pharmacol. Physiol. 27, 745-750. doi: 10.1046/j.1440-1681. 2000.03326.x
Perez-Pinzon, M. A., Yenari, M. A., Sun, G. H., Kunis, D. M., and Steinberg, G. K. (1997). SNX-111, a novel, presynaptic N-type calcium channel antagonist, is neuroprotective against focal cerebral ischemia in rabbits. J. Neurol. Sci. 153, 25-31. doi: 10.1016/S0022-510X(97)00196-2

Phillips, J. L., Ivaschuk, O., Ishida-Jones, T., Jones, R. A., Campbell-Beachler, M., and Haggren, W. (1998). DNA damage in Molt-4 T-lymphoblastoid cells exposed to cellular telephone radiofrequency fields in vitro. Bioelectrochem. Bioenerg. 45, 103-110. doi: 10.1016/S0302-4598(98)00074-9

Phillis, J. W., Smith-Barbour, M., and O'Regan, M. H. (1996). Changes in extracellular amino acid neurotransmitters and purines during and following ischemias of different durations in the rat cerebral cortex. Neurochem. Int. 29, 115-120. doi: 10.1016/0197-0186(95)00154-9

Phisalix, C., and Bertrand, G. (1894). Sur la propriété antitoxique du sang des animaux vaccinés contre le venin de vipère. C. R. Acad. Sci. 46:111-113.

Picconi, B., Piccoli, G., and Calabresi, P. (2012). Synaptic dysfunction in Parkinson's disease. Adv. Exp. Med. Biol. 970, 553-572. doi: 10.1007/978-37091-0932-8_24

Pignataro, G., Simon, R. P., and Xiong, Z. G. (2007). Prolonged activation of ASICla and the time window for neuroprotection in cerebral ischaemia. Brain 130, 151-158. doi: 10.1093/brain/awl325

Pineda, S. S., Undheim, E. A., Rupasinghe, D. B., Ikonomopoulou, M. P., and King, G. F. (2014). Spider venomics: implications for drug discovery. Future Med. Chem. 6, 1699-1714. doi: 10.4155/fmc.14.103

Pinheiro, A. C., da Silva, A. J., Prado, M. A., Cordeiro Mdo, N., Richardson, M., Batista, M. C., et al. (2009). Phoneutria spider toxins block ischemiainduced glutamate release, neuronal death, and loss of neurotransmission in hippocampus. Hippocampus 19, 1123-1129. doi: 10.1002/hipo.20580

Pinheiro, A. C., Gomez, R. S., Massensini, A. R., Cordeiro, M. N., Richardson, M., Romano-Silva, M. A., et al. (2006). Neuroprotective effect on brain injury by neurotoxins from the spider Phoneutria nigriventer. Neurochem. Int. 49, 543-547. doi: 10.1016/j.neuint.2006.04.009

Plassman, B. L., Langa, K. M., Fisher, G. G., Heeringa, S. G., Weir, D. R., Ofstedal, M. B., et al. (2007). Prevalence of dementia in the United States: the aging, demographics, and memory study. Neuroepidemiology 29, 125-132. doi: $10.1159 / 000109998$

Platelet Glycoprotein IIb/IIIa in Unstable Angina: Receptor Suppression Using Integrilin Therapy (PURSUIT) Trial Investigators (1998). Inhibition of platelet glycoprotein IIb/IIIa with eptifibatide in patients with acute coronary syndromes. N. Engl. J. Med. 339, 436-443.

Podewils, L. J., Guallar, E., Kuller, L. H., Fried, L. P., Lopez, O. L., Carlson, M., et al. (2005). Physical activity, APOE genotype, and dementia risk: findings from the cardiovascular health cognition study. Am. J. Epidemiol. 161, 639-651. doi: 10.1093/aje/kwi092

Polymeropoulos, M. H., Lavedan, C., Leroy, E., Ide, S. E., Dehejia, A., Dutra, A., et al. (1997). Mutation in the alpha-synuclein gene identified in families with Parkinson's disease. Science 276, 2045-2047. doi: 10.1126/science.276.5321.2045

Przedborski, S., and Vila, M. (2003). The 1-methyl-4-phenyl-1,2,3,6tetrahydropyridine mouse model: a tool to explore the pathogenesis of Parkinson's disease. Ann. N. Y. Acad. Sci. 991, 189-198. doi: 10.1111/j. 1749-6632.2003.tb07476.x

Qian, L., Flood, P. M., and Hong, J. S. (2010). Neuroinflammation is a key player in Parkinson's disease and a prime target for therapy. J. Neural. Transm. 117, 971-979. doi: 10.1007/s00702-010-0428-1

Quillinan, N., Herson, P. S., and Traystman, R. J. (2016). Neuropathophysiology of brain injury. Anesthesiol. Clin. 34, 453-464. doi: 10.1016/j.anclin.2016.04.011

Raichle, M. E. (1983). The pathophysiology of brain ischemia. Ann. Neurol. 13, 2-10. doi: 10.1002/ana.410130103

Ramirez, A. I., de Hoz, R., Salobrar-Garcia, E., Salazar, J. J., Rojas, B., Ajoy, D., et al. (2017). The role of microglia in retinal neurodegeneration: Alzheimer's disease, Parkinson, and glaucoma. Front. Aging Neurosci. 9:214. doi: 10.3389/fnagi.2017. 00214

Ray, P. D., Huang, B. W., and Tsuji, Y. (2012). Reactive oxygen species (ROS) homeostasis and redox regulation in cellular signaling. Cell. Signal. 24, 981-990. doi: 10.1016/j.cellsig.2012.01.008

Reis, H. J., Prado, M. A., Kalapothakis, E., Cordeiro, M. N., Diniz, C. R., De Marco, L. A., et al. (1999). Inhibition of glutamate uptake by a polypeptide toxin (phoneutriatoxin 3-4) from the spider Phoneutria nigriventer. Biochem. J. 343(Pt 2), 413-418. doi: 10.1042/bj3430413 
Reynolds, A. D., Banerjee, R., Liu, J., Gendelman, H. E., and Mosley, R. L. (2007). Neuroprotective activities of $\mathrm{CD} 4+\mathrm{CD} 25+$ regulatory $\mathrm{T}$ cells in an animal model of Parkinson's disease. J. Leukoc. Biol. 82, 1083-1094. doi: 10.1189/jlb. 0507296

Richter, C., Schweizer, M., Cossarizza, A., and Franceschi, C. (1996). Control of apoptosis by the cellular ATP level. FEBS Lett. 378, 107-110. doi: 10.1016/00145793(95)01431-4

Rigo, F. K., Rossato, M. F., Trevisan, G., De Pra, S. D., Ineu, R. P., Duarte, M. B., et al. (2017). PhKv a toxin isolated from the spider venom induces antinociception by inhibition of cholinesterase activating cholinergic system. Scand. J. Pain 17, 203-210. doi: 10.1016/j.sjpain.2017.09.019

Roberts, A. L., Johnson, N. J., Cudkowicz, M. E., Eum, K. D., and Weisskopf, M. G. (2016). Job-related formaldehyde exposure and ALS mortality in the USA. J. Neurol. Neurosurg. Psychiatry 87, 786-788. doi: 10.1136/jnnp-2015310750

Rocha, E. S. M., Beraldo, W. T., and Rosenfeld, G. (1949). Bradykinin, a hypotensive and smooth muscle stimulating factor released from plasma globulin by snake venoms and by trypsin. Am. J. Physiol. 156, 261-273. doi: 10.1152/ajplegacy.1949.156.2.261

Roe, C. M., Xiong, C., Miller, J. P., and Morris, J. C. (2007). Education and Alzheimer disease without dementia: support for the cognitive reserve hypothesis. Neurology 68, 223-228. doi: 10.1212/01.wnl.0000251303.50459.8a

Rogaev, E. I., Sherrington, R., Rogaeva, E. A., Levesque, G., Ikeda, M., Liang, Y., et al. (1995). Familial Alzheimer's disease in kindreds with missense mutations in a gene on chromosome 1 related to the Alzheimer's disease type 3 gene. Nature 376, 775-778. doi: 10.1038/376775a0

Rojo, L. E., Fernandez, J. A., Maccioni, A. A., Jimenez, J. M., and Maccioni, R. B. (2008). Neuroinflammation: implications for the pathogenesis and molecular diagnosis of Alzheimer's disease. Arch. Med. Res. 39, 1-16. doi: 10.1016/j. arcmed.2007.10.001

Rosano, G. L., and Ceccarelli, E. A. (2014). Recombinant protein expression in Escherichia coli: advances and challenges. Front. Microbiol. 5:172. doi: 10.3389/ fmicb.2014.00172

Ross, G. W., Petrovitch, H., Abbott, R. D., Nelson, J., Markesbery, W., Davis, D., et al. (2004). Parkinsonian signs and substantia nigra neuron density in decendents elders without PD. Ann. Neurol. 56, 532-539. doi: 10.1002/ana. 20226

Rossi, D. J., Brady, J. D., and Mohr, C. (2007). Astrocyte metabolism and signaling during brain ischemia. Nat. Neurosci. 10, 1377-1386. doi: 10.1038/nn2004

Rowland, L. P., and Shneider, N. A. (2001). Amyotrophic lateral sclerosis. N. Engl. J. Med. 344, 1688-1700. doi: 10.1056/NEJM200105313442207

Saez, N. J., Mobli, M., Bieri, M., Chassagnon, I. R., Malde, A. K., Gamsjaeger, R., et al. (2011). A dynamic pharmacophore drives the interaction between Psalmotoxin-1 and the putative drug target acid-sensing ion channel 1a. Mol. Pharmacol. 80, 796-808. doi: 10.1124/mol.111.072207

Sakaguchi, S., Yamaguchi, T., Nomura, T., and Ono, M. (2008). Regulatory T cells and immune tolerance. Cell 133, 775-787. doi: 10.1016/j.cell.2008.05.009

Salthun-Lassalle, B., Hirsch, E. C., Wolfart, J., Ruberg, M., and Michel, P. P. (2004). Rescue of mesencephalic dopaminergic neurons in culture by lowlevel stimulation of voltage-gated sodium channels. J. Neurosci. 24, 5922-5930. doi: 10.1523/JNEUROSCI.5668-03.2004

Schubert, P., Keller, F., Nakamura, Y., and Rudolphi, K. (1994). The use of ion-sensitive electrodes and fluorescence imaging in hippocampal slices for studying pathological changes of intracellular $\mathrm{Ca}^{2+}$ regulation. J. Neural Transm. Suppl. 44, 73-85. doi: 10.1007/978-3-7091-9350-1_6

Selkoe, D. J. (2002). Alzheimer's disease is a synaptic failure. Science 298, 789-791. doi: 10.1126/science.1074069

Sepers, M. D., and Raymond, L. A. (2014). Mechanisms of synaptic dysfunction and excitotoxicity in Huntington's disease. Drug Discov. Today 19, 990-996. doi: 10.1016/j.drudis.2014.02.006

Sherrington, R., Rogaev, E. I., Liang, Y., Rogaeva, E. A., Levesque, G., Ikeda, M., et al. (1995). Cloning of a gene bearing missense mutations in early-onset familial Alzheimer's disease. Nature 375, 754-760. doi: 10.1038/375754a0

Shi, Y. (2002). Mechanisms of caspase activation and inhibition during apoptosis. Mol. Cell. 9, 459-470. doi: 10.1016/S1097-2765(02)00482-3

Siesjo, B. K. (1992). Pathophysiology and treatment of focal cerebral ischemia. Part II: mechanisms of damage and treatment. J. Neurosurg. 77, 337-354. doi: $10.3171 /$ jns.1992.77.3.0337
Silva, F. R., Batista, E. M., Gomez, M. V., Kushmerick, C., Da Silva, J. F., Cordeiro, M. N., et al. (2016). The Phoneutria nigriventer spider toxin, PnTx4-5-5, promotes neuronal survival by blocking NMDA receptors. Toxicon $112,16-21$. doi: 10.1016/j.toxicon.2016.01.056

Silver, I. A., Deas, J., and Erecinska, M. (1997). Ion homeostasis in brain cells: differences in intracellular ion responses to energy limitation between cultured neurons and glial cells. Neuroscience 78, 589-601. doi: 10.1016/S0306-4522(96) 00600-8

Sinha, K., Das, J., Pal, P. B., and Sil, P. C. (2013). Oxidative stress: the mitochondriadependent and mitochondria-independent pathways of apoptosis. Arch. Toxicol. 87, 1157-1180. doi: 10.1007/s00204-013-1034-4

Smith, A. I., Rajapakse, N. W., Kleifeld, O., Lomonte, B., Sikanyika, N. L., Spicer, A. J., et al. (2016). Corrigendum: N-terminal domain of Bothrops asper myotoxin II enhances the activity of endothelin converting enzyme-1 and neprilysin. Sci. Rep. 6:22413. doi: 10.1038/srep22413

Smith, H. S., and Deer, T. R. (2009). Safety and efficacy of intrathecal ziconotide in the management of severe chronic pain. Ther. Clin. Risk Manag. 5, 521-534. doi: $10.2147 /$ TCRM.S4438

Smollich, M., Gotte, M., Yip, G. W., Yong, E. S., Kersting, C., Fischgrabe, J., et al. (2007). On the role of endothelin-converting enzyme-1 (ECE-1) and neprilysin in human breast cancer. Breast Cancer Res. Treat. 106, 361-369. doi: 10.1007/s10549-007-9516-9

Son, D. J., Lee, J. W., Lee, Y. H., Song, H. S., Lee, C. K., and Hong, J. T. (2007). Therapeutic application of anti-arthritis, pain-releasing, and anti-cancer effects of bee venom and its constituent compounds. Pharmacol. Ther. 115, 246-270. doi: 10.1016/j.pharmthera.2007.04.004

Stathis, P., Konitsiotis, S., and Antonini, A. (2015). Dopamine agonists early monotherapy for the delay of development of levodopa-induced dyskinesias. Expert Rev. Neurother. 15, 207-213. doi: 10.1586/14737175.2015.1001747

Stefan, A., Ceccarelli, A., Conte, E., Monton Silva, A., and Hochkoeppler, A. (2015). The multifaceted benefits of protein co-expression in Escherichia coli. J. Vis. Exp. 96:52431. doi: 10.3791/52431

Stowe, R. L., Ives, N. J., Clarke, C., van Hilten, J., Ferreira, J., Hawker, R. J., et al. (2008). Dopamine agonist therapy in early Parkinson's disease. Cochrane Database Syst. Rev. 2:CD006564. doi: 10.1002/14651858.CD006564.pub2

Surin, A. M., Gorbacheva, L. R., Savinkova, I. G., Sharipov, R. R., Khodorov, B. I., and Pinelis, V. G. (2014). Study on ATP concentration changes in cytosol of individual cultured neurons during glutamate-induced deregulation of calcium homeostasis. Biochemistry 79, 146-157. doi: 10.1134/S0006297914020084

Taipa, R., Pinho, J., and Melo-Pires, M. (2012). Clinico-pathological correlations of the most common neurodegenerative dementias. Front. Neurol. 3:68. doi: 10.3389/fneur.2012.00068

Takizawa, S., Matsushima, K., Fujita, H., Nanri, K., Ogawa, S., and Shinohara, Y. (1995). A selective $\mathrm{N}$-type calcium channel antagonist reduces extracellular glutamate release and infarct volume in focal cerebral ischemia. J. Cereb. Blood Flow Metab. 15, 611-618. doi: 10.1038/jcbfm. 1995.75

Talpade, D. J., Greene, J. G., Higgins, D. S. Jr., and Greenamyre, J. T. (2000). In vivo labeling of mitochondrial complex I (NADH:ubiquinone oxidoreductase) in rat brain using [(3)H]dihydrorotenone. J. Neurochem. 75, 2611-2621. doi: 10.1046/ j.1471-4159.2000.0752611.x

Tang, Y., and Le, W. (2016). Differential roles of M1 and M2 microglia in neurodegenerative diseases. Mol. Neurobiol. 53, 1181-1194. doi: 10.1007/ s12035-014-9070-5

Teismann, P., and Schulz, J. B. (2004). Cellular pathology of Parkinson's disease: astrocytes, microglia and inflammation. Cell Tissue Res. 318, 149-161. doi: 10.1007/s00441-004-0944-0

Terry, R. D., Masliah, E., Salmon, D. P., Butters, N., DeTeresa, R., Hill, R., et al. (1991). Physical basis of cognitive alterations in Alzheimer's disease: synapse loss is the major correlate of cognitive impairment. Ann. Neurol. 30, 572-580. doi: 10.1002/ana.410300410

Thornberry, N. A., and Lazebnik, Y. (1998). Caspases: enemies within. Science 281, 1312-1316. doi: 10.1126/science.281.5381.1312

Toulorge, D., Guerreiro, S., Hild, A., Maskos, U., Hirsch, E. C., and Michel, P. P. (2011). Neuroprotection of midbrain dopamine neurons by nicotine is gated by cytoplasmic $\mathrm{Ca}^{2+}$. FASEB J. 25, 2563-2573. doi: 10.1096/fj.11-182824

Touyz, R. M., Tabet, F., and Schiffrin, E. L. (2003). Redox-dependent signalling by angiotensin II and vascular remodelling in hypertension. Clin. Exp. Pharmacol. Physiol. 30, 860-866. doi: 10.1046/j.1440-1681.2003.03930.x 
Triplitt, C., and Chiquette, E. (2006). Exenatide: from the Gila monster to the pharmacy. J. Am. Pharm. Assoc. 46, 44-52; quiz53-55. doi: 10.1331/ 154434506775268698

Tsai, I. H., Lu, P. J., and Su, J. C. (1996). Two types of Russell's viper revealed by variation in phospholipases A2 from venom of the subspecies. Toxicon 34, 99-109. doi: 10.1016/0041-0101(95)00114-X

Uchitel, O. D. (1997). Toxins affecting calcium channels in neurons. Toxicon 35, 1161-1191. doi: 10.1016/S0041-0101(96)00210-3

Valentino, K., Newcomb, R., Gadbois, T., Singh, T., Bowersox, S., Bitner, S., et al. (1993). A selective $\mathrm{N}$-type calcium channel antagonist protects against neuronal loss after global cerebral ischemia. Proc. Natl. Acad. Sci. U.S.A. 90, 7894-7897. doi: $10.1073 /$ pnas.90.16.7894

Van Dam, D., and De Deyn, P. P. (2006). Drug discovery in dementia: the role of rodent models. Nat. Rev. Drug Discov. 5, 956-970. doi: 10.1038/nrd2075

Vergun, O., Han, Y. Y., and Reynolds, I. J. (2003). Glucose deprivation produces a prolonged increase in sensitivity to glutamate in cultured rat cortical neurons. Exp. Neurol. 183, 682-694. doi: 10.1016/S0014-4886(03)00243-7

Walling, A. D. (1999). Amyotrophic lateral sclerosis: Lou Gehrig's disease. Am. Fam. Physician 59, 1489-1496.

Wang, Q., Liu, Y., and Zhou, J. (2015). Neuroinflammation in Parkinson's disease and its potential as therapeutic target. Transl. Neurodegener. 4:19. doi: 10.1186/ s40035-015-0042-0

Wang, T., Wang, S. W., Zhang, Y., Wu, X. F., Peng, Y., Cao, Z., et al. (2014). Scorpion venom heat-resistant peptide (SVHRP) enhances neurogenesis and neurite outgrowth of immature neurons in adult mice by up-regulating brainderived neurotrophic factor (BDNF). PLoS One 9:e109977. doi: 10.1371/journal. pone. 0109977

Wang, X., Treistman, S. N., and Lemos, J. R. (1992). Two types of high-threshold calcium currents inhibited by omega-conotoxin in nerve terminals of rat neurohypophysis. J. Physiol. 445, 181-199. doi: 10.1113/jphysiol.1992.sp018919

Wang, Y., and Qin, Z. H. (2010). Molecular and cellular mechanisms of excitotoxic neuronal death. Apoptosis 15, 1382-1402. doi: 10.1007/s10495-010-0481-0

Wang, Y. R., Liu, R. Y., Wang, L. C., Mao, H. F., and Chen, J. Q. (2007). Effect of Huwentoxin-I on the Fas and TNF apoptosis pathway in the hippocampus of rat with global cerebral ischemia. Toxicon 50, 1085-1094. doi: 10.1016/j.toxicon. 2007.07.020

Wang, Z., Wang, W., Shao, Z., Gao, B., Li, J., Ma, J., et al. (2009). Eukaryotic expression and purification of anti-epilepsy peptide of Buthus martensii Karsch and its protein interactions. Mol. Cell. Biochem. 330, 97-104. doi: 10.1007/ s11010-009-0104-7

Waqar, M., and Batool, S. (2015). In silico analysis of binding of neurotoxic venom ligands with acetylcholinesterase for therapeutic use in treatment of Alzheimer's disease. J. Theor. Biol. 372, 107-117. doi: 10.1016/j.jtbi.2015.02.028

Weber, A. J., Chen, H., Hubbard, W. C., and Kaufman, P. L. (2000). Experimental glaucoma and cell size, density, and number in the primate lateral geniculate nucleus. Invest. Ophthalmol. Vis. Sci. 41, 1370-1379.

Weisskopf, M. G., Morozova, N., O’Reilly, E. J., McCullough, M. L., Calle, E. E., Thun, M. J., et al. (2009). Prospective study of chemical exposures and amyotrophic lateral sclerosis. J. Neurol. Neurosurg. Psychiatry 80, 558-561. doi: 10.1136/jnnp.2008.156976

Wesselius, T., Heersema, D. J., Mostert, J. P., Heerings, M., Admiraal-Behloul, F., Talebian, A., et al. (2005). A randomized crossover study of bee sting therapy for multiple sclerosis. Neurology 65, 1764-1768. doi: 10.1212/01.wnl.0000184442. 02551.4b

Wheeler, D. B., Randall, A., and Tsien, R. W. (1994). Roles of N-type and Q-type $\mathrm{Ca} 2+$ channels in supporting hippocampal synaptic transmission. Science 264, 107-111. doi: 10.1126/science.7832825

Wu, D., and Yotnda, P. (2011). Production and detection of reactive oxygen species (ROS) in cancers. J. Vis. Exp. 57:3357. doi: 10.3791/3357

Xiong, Z. G., Zhu, X. M., Chu, X. P., Minami, M., Hey, J., Wei, W. L., et al. (2004). Neuroprotection in ischemia: blocking calcium-permeable acid-sensing ion channels. Cell 118, 687-698. doi: 10.1016/j.cell.2004.08.026

Xu, H., An, D., Yin, S. M., Chen, W., Zhao, D., Meng, X., et al. (2015). [The alterations of apoptosis factor Bcl-2/Bax in the early Parkinson's disease rats and the protective effect of scorpion venom derived activity peptide]. Zhongguo Ying Yong Sheng Li Xue Za Zhi 31, 225-229.

Yan, M. H., Wang, X., and Zhu, X. (2013). Mitochondrial defects and oxidative stress in Alzheimer disease and Parkinson disease. Free Radic. Biol. Med. 62, 90-101. doi: 10.1016/j.freeradbiomed.2012.11.014

Yang, E. J., Jiang, J. H., Lee, S. M., Yang, S. C., Hwang, H. S., Lee, M. S., et al. (2010). Bee venom attenuates neuroinflammatory events and extends survival in amyotrophic lateral sclerosis models. J. Neuroinflammation 7:69. doi: 10.1186/1742-2094-7-69

Yang, E. J., Kim, S. H., Yang, S. C., Lee, S. M., and Choi, S. M. (2011). Melittin restores proteasome function in an animal model of ALS. J. Neuroinflammation 8:69. doi: 10.1186/1742-2094-8-69

Yang, Z. J., Ni, X., Carter, E. L., Kibler, K., Martin, L. J., and Koehler, R. C. (2011). Neuroprotective effect of acid-sensing ion channel inhibitor psalmotoxin-1 after hypoxia-ischemia in newborn piglet striatum. Neurobiol. Dis. 43, 446-454. doi: 10.1016/j.nbd.2011.04.018

Ye, M., Chung, H. S., Lee, C., Hyun Song, J., Shim, I., Kim, Y. S., et al. (2016a). Bee venom phospholipase A2 ameliorates motor dysfunction and modulates microglia activation in Parkinson's disease alpha-synuclein transgenic mice. Exp. Mol. Med. 48:e244. doi: 10.1038/emm.2016.49

Ye, M., Chung, H. S., Lee, C., Yoon, M. S., Yu, A. R., Kim, J. S., et al. (2016b). Neuroprotective effects of bee venom phospholipase A2 in the 3xTg AD mouse model of Alzheimer's disease. J. Neuroinflammation 13:10. doi: 10.1186/s12974016-0476-z

Yin, S. M., Zhao, D., Yu, D. Q., Li, S. L., An, D., Peng, Y., et al. (2014). Neuroprotection by scorpion venom heat resistant peptide in 6hydroxydopamine rat model of early-stage Parkinson's disease. Sheng Li Xue Bao 66, 658-666.

Yu, Y., Hayashi, S., Cai, X., Fang, C., Shi, W., Tsutsui, H., et al. (2014). Pu-erh tea extract induces the degradation of FET family proteins involved in the pathogenesis of amyotrophic lateral sclerosis. Biomed. Res. Int. 2014:254680. doi: $10.1155 / 2014 / 254680$

Yucel, Y. H., Zhang, Q., Weinreb, R. N., Kaufman, P. L., and Gupta, N. (2003). Effects of retinal ganglion cell loss on magno-, parvo-, koniocellular pathways in the lateral geniculate nucleus and visual cortex in glaucoma. Prog. Retin. Eye Res. 22, 465-481. doi: 10.1016/S1350-9462(03)00026-0

Zarei, S., Carr, K., Reiley, L., Diaz, K., Guerra, O., Altamirano, P. F., et al. (2015). A comprehensive review of amyotrophic lateral sclerosis. Surg. Neurol. Int. 6:171. doi: 10.4103/2152-7806.169561

Zhang, X. G., Wang, X., Zhou, T. T., Wu, X. F., Peng, Y., Zhang, W. Q., et al. (2016). Scorpion venom heat-resistant peptide protects transgenic caenorhabditis elegans from beta-amyloid toxicity. Front. Pharmacol. 7:227. doi: 10.3389/fphar. 2016.00227

Zhang, Y. (2015). Why do we study animal toxins? Dongwuxue Yanjiu 36, 183-222. Zhao, Q., Smith, M. L., and Siesjo, B. K. (1994). The omega-conopeptide SNX-111, an N-type calcium channel blocker, dramatically ameliorates brain damage due to transient focal ischaemia. Acta Physiol. Scand. 150, 459-461. doi: 10.1111/j. 1748-1716.1994.tb09713.x

Zuo, L., Hemmelgarn, B. T., Chuang, C. C., and Best, T. M. (2015). The role of oxidative stress-induced epigenetic alterations in amyloid-beta production in Alzheimer's disease. Oxid. Med. Cell. Longev. 2015:604658. doi: 10.1155/2015/ 604658

Conflict of Interest Statement: The authors declare that the research was conducted in the absence of any commercial or financial relationships that could be construed as a potential conflict of interest.

Copyright (c) 2018 de Souza, Goncalves, Gomez, Vieira and Ribeiro. This is an openaccess article distributed under the terms of the Creative Commons Attribution License (CC BY). The use, distribution or reproduction in other forums is permitted, provided the original author(s) and the copyright owner are credited and that the original publication in this journal is cited, in accordance with accepted academic practice. No use, distribution or reproduction is permitted which does not comply with these terms. 